\section{Methods of Constructing a Pine Tree Substrate from Various Wood Particle Sizes, Organic Amendments, and Sand for Desired Physical Properties and Plant Growth}

\author{
Brian E. Jackson ${ }^{1,4}$ \\ North Carolina State University, Department of Horticultural Science, 114 \\ Kilgore Hall, Campus Box 7609, Raleigh, NC 27695
}

\section{Robert D. Wright ${ }^{2}$ and Michael C. Barnes ${ }^{3}$ \\ Department of Horticulture, Virginia Polytechnic Institute and State University, Blacksburg, VA 24061}

Additional index words. air space, container capacity, container substrate, loblolly pine, pine bark, pine chips, wood substrate

\begin{abstract}
The use of freshly harvested and processed pine trees as a container substrate for greenhouse and nursery crop production is a relatively new concept, and fundamental knowledge of the construction of a pine tree substrate (PTS) for optimal physical properties is insufficient. Therefore, this research was conducted to determine the influence of mixing PTSs produced with different wood particle sizes and adding other amendments to PTS on substrate physical properties and plant growth compared with traditional substrates. Coarse pine wood chips produced from 15-year-old loblolly pine trees (Pinus taeda $\mathrm{L}$.) were ground in a hammermill fitted with either a 4.76-mm screen or with no screen (PTS-NS) allowing a fine and a coarse particle PTS to be produced. Increasing proportions of the finer $(4.76-\mathrm{mm})$ PTS to the coarser PTS (PTS-NS) resulted in increased container capacity (CC) and shoot growth of 'Inca Gold' marigold (Tagetes erecta L.). In another study, PTSs were manufactured in a hammermill fitted with different screen sizes: 4.76, 6.35, 9.54, or $15.8 \mathrm{~mm}$ as well as PTS-NS. After being hammermilled, each of the five PTSs was then amended (by mixing) with $10 \%$ sand (PTS-S), $\mathbf{2 5 \%}$ peatmoss (PTS-PM), or left unamended. Pine tree substrates were also produced by adding $25 \%$ aged pine bark (PB) to pine wood chips before being ground in a hammermill with each of the five screen sizes mentioned (PTS-HPB). These five substrates were used unamended as well as amended with $10 \%$ sand after grinding (PTSHPBS). Control treatments included peat-lite (PL) and $100 \%$ aged PB for a total of 27 substrates evaluated in this study. Container capacity and marigold growth increased as screen size decreased and with the additions of peatmoss (PTS-PM) or hammering with PB (PTS-HPB) to PTS. Container capacity for all substrates amended with peatmoss or $P B$ was within the recommended range of $45 \%$ to $65 \%$ for container substrates, but only with the more finely ground PTS-4.76-mm resulted in marigold growth comparable to PL and PB. However, when the PTS-NS was amended by mixing in $25 \%$ peat or hammering with $25 \% \mathrm{~PB}$, growth of marigold was equal to plants grown in PL or PB. In a third study, hammering PTS-NS with $25 \%$ PB followed by the addition of $10 \%$ sand increased dry weight of both azalea (Rhododendron $\times$ hybrida 'Girard Pleasant White') and spirea (Spiraea nipponica Maxim. 'Snowmound') resulting in growth equal to plants grown in $100 \%$ PB. This work shows that amending coarsely ground PTS with finer particle PTS or with other materials (peatmoss, aged $\mathrm{PB}$, or sand) can result in a substrate with comparable physical properties such as $\mathrm{CC}$ and plant growth compared with $100 \%$ PL or PB.
\end{abstract}

Recent work demonstrating the successful use of pine tree substrates (PTS) for greenhouse and nursery crop production has gained considerable interest from growers and substrate manufacturers. Pine tree substrates can be produced from pine trees that are chipped and ground (with or without bark, limbs, needles, and so on) in a hammermill or from clean chip residual (CCR: $\approx 40 \%$ pine wood, $50 \%$ bark, and $10 \%$ needles), which is produced from byproducts of the pine treeharvesting process (Boyer et al., 2006; Fain use as a container substrate (Jackson and Wright, 2009b; Jackson et al., 2008b; Saunders et al., 2006; Wright et al., 2008b). Research with various PTSs and CCR has also shown that a wide variety of nursery (Boyer et al., 2009; Jackson et al., 2008a; Wright et al., 2006) and greenhouse (Boyer et al., 2008; Fain et al., 2008a; Jackson et al., 2008b; Wright et al., 2008a) crops can be produced with similar quality to plants grown in peatmoss or PB.

The southern United States, which produces $60 \%$ of the nation's timber products and more timber than any other country in the world, has been quoted as being the "woodbasket of the world" as a result of increasing productivity of pine plantations, in particular loblolly pine (Prestemon and Abt, 2002). Research by Samuelson et al. (2008) showed that short-rotation pine plantations in the southern United States would better exploit the genetic growth potential of loblolly pine. The short rotation/production of loblolly pines used for producing PTS (10 to 15 years) could potentially open a significant avenue for maximum use of young pine plantations in the southeast. In addition to the production of PTS from loblolly pines, additional research by Fain et al. (2008a) has shown that slash pine (Pinus elliottii Engelm.) and longleaf pine (Pinus palustris Mill.) are potential tree species for producing PTSs in the southern United States. Wright et al. (2009) reported that eastern white pine (Pinus strobus L.) could also serve as a source of pine for PTS production, which could be potentially significant to the greenhouse and nursery industry in the northeastern United States where loblolly pine cannot be grown.

Some advantages of PTS are: 1) PTS can be produced in close proximity to growers and substrate companies where pine trees are abundant, which minimizes transportation costs of long-distance shipping; 2) PTS can be used immediately after milling and does not have to be composted or aged before use as a container substrate; and 3) physical properties such as container capacity (CC) and air space (AS) can be easily altered during the manufacturing process to meet the needs of particular plants and container sizes by the degree of pine wood chip grinding in a hammermill. For example, Jackson and Wright (2009a) and Saunders et al. (2006) demonstrated that AS ranged from $18 \%$ to $39 \%$ for PTS ground in a hammermill with screens ranging in size from 1.6 $\mathrm{mm}$ to $6.35 \mathrm{~mm}$, respectively. An AS range of $10 \%$ to $30 \%$ is recommended for container plant production (Yeager et al., 2007). Container capacity of those same substrates ranged from $43 \%$ to $65 \%$, which is near or within the range of $45 \%$ to $65 \%$ normally considered acceptable for substrates. Marigold plants (Tagetes erecta Big. 'Inca Gold'), grown in a $100 \%$ PTS with $18 \%$ AS and $65 \%$ CC (produced with a 1.6-mm hammermill screen), were as large as plants grown in a peat-lite [PL; $80 \%$ peatmoss $/ 20 \%$ perlite (v/ v)] substrate that had similar AS and CC $(16.8 \%$ and $65 \%$, respectively; Saunders 
et al., 2006). These results demonstrate that a $100 \%$ PTS can be produced with physical properties similar to commercial substrates if ground finely enough and that plant growth in $100 \%$ PTS is comparable to growth in traditional peat-based substrates.

However, producing a PTS with a particle size fine enough to possess an adequate water-holding capacity similar to peatmoss or aged PB may be too costly as a result of expenses associated with grinding (primarily energy costs). Another approach would be to mix larger PTS particles with various proportions of fine PTS particles (less than 0.5 $\mathrm{mm}$ ), which could result in a PTS with adequate CC and AS. Research with 100\% PB substrates has shown that substrate particles smaller than $0.5 \mathrm{~mm}$ (fines) greatly influence the physical properties (AS and CC) in containers (Handreck, 1983) and that considerable variation in the proportions of substrate particles larger than $0.5 \mathrm{~mm}$ have a minor influence on the physical properties (AS and CC). The intermixing of various PTS particle sizes should result in reduced production costs for PTS because relatively small amounts (percentage) of finely ground PTS (more costly to produce than coarsely ground PTS) would be needed to supply enough fines to give desired $\mathrm{CC}$ of the substrate. Another approach to increasing $\mathrm{CC}$ by adding fine particles would be to amend large-particle PTS with peatmoss, aged PB, sand, or other organic or inorganic materials that characteristically have a high percentage of fines. The additions of peatmoss or aged PB would also increase the cation exchange capacity (CEC) of PTS which is low (2.1 $\mathrm{cmol} \cdot \mathrm{L}^{-1}$; Wright et al., 2008a) compared with peatmoss and aged PB: 10 and 12 $\mathrm{cmol} \cdot \mathrm{L}^{-1}$, respectively (Nelson, 2003). Increasing CEC could help reduce extra nitrogen $(\mathrm{N})$ requirements needed for plant growth in $100 \%$ PTS compared with peatmoss or PB (Wright et al., 2008a). In support of this approach, Jackson et al. (2008b) showed that adding $25 \%$ peatmoss $(\mathrm{v} / \mathrm{v})$ to PTS ground through a $4.76-\mathrm{mm}$ hammermill screen increased CC and growth of poinsettia compared with $4.76 \mathrm{~mm}$ PTS without peat additions. There is also evidence that plants

Received for publication 22 June 2009. Accepted for publication 20 Nov. 2009.

This research was funded in part by the American Floral Endowment, Virginia Agricultural Council, the Virginia Nursery and Landscape Association, and the Virginia Tobacco Commission.

Technical assistance of Joyce Shelton is gratefully acknowledged.

Use of trade names does not imply endorsement of the products named nor criticism of similar ones not mentioned.

${ }^{1}$ Former Graduate Research Assistant. Currently: Assistant Professor, Department of Horticultural Science, North Carolina State University, Raleigh, NC 27695.

${ }^{2}$ Professor.

${ }^{3}$ Former Research Technician.

${ }^{4}$ To whom reprint requests should be addressed; e-mail brian_jackson@ncsu.edu. grown in peat-amended PTS require less N for optimal growth than plants grown in PTS without peat (Jackson and Wright, 2009c).

Sand is one of the most commonly used inorganic amendments in soilless container substrates because it provides ballast and can help overcome rewetting problems (Guttormsen, 1974). Combing sand with organic components decreases the infiltration (the downward entry of water through the substrate surface and into the substrate) rate of irrigation water as it moves through the substrate profile, particularly in fresh or less decomposed organic components (Bilderback and Jones, 2001). Water percolation (the downward movement of water through the substrate profile/container) rate also decreases as the percentage of sand increases in a PB and sand substrate mixture (Brown and Pokorny, 1975). The slower infiltration rate of water in sand-amended substrates promotes more thorough wetting of the substrate compared with a $100 \%$ organic substrate in which water can channel rapidly to the bottom of the container (Bilderback and Jones, 2001).

The formation/engineering of substrates for greenhouse and nursery crop production has been achieved several times since soilless media began being the primary substrate in container production including the University of California (UC) mixes (Matkin and Chandler, 1957), Cornell "Peat-lite" mixes (Boodley and Sheldrake, 1964), and PB-based substrates (Krafka and Pokorny, 1979; Pokorny and Henny, 1984a, 1984b). Research with PB has thoroughly described the construction/engineering of $100 \% \mathrm{~PB}$ substrates and how its physical properties change when amended with other organic materials (Bilderback and Fonteno, 1993; Lemaire et al., 1980; Nkongolo et al., 2000; Tyler et al., 1993), mineral aggregates (Owen et al., 2007), clay (Handreck and Black, 2005), and inorganic materials (Brown and Pokorny, 1975; Raviv and Lieth, 2008). One cannot assume that wood-based substrates have the same physical properties as $\mathrm{PB}$ (aged or fresh) when constructed/formulated into a container substrate. Research has shown the range in physical properties of woodbased substrates (Boyer et al., 2009; Gruda and Schnitzler, 2004; Gruda et al., 2000; Jackson, 2008), but limited information is available on the manufacturing (and methods thereof) of wood-based substrates and how those methods influence physical properties. Previous research with nonwood-based substrates (peatmoss, aged and fresh PB, coir, compost) specify that a high proportion of particles in the range from $0.5 \mathrm{~mm}$ to $\approx 6.0$ $\mathrm{mm}$ are needed to supply the appropriate air and water regimes. Numerous authors reported that substrate particles less than $0.5 \mathrm{~mm}$ (fines) are needed for adequate water-holding properties, and the recommend amount of these fines has ranged from $10 \%$ to $15 \%$ (Goodwin, 1980) to 36\% (Thomas and Perry, 1980).

Because wood-based substrates will be more widely used in the trade, generating information about constructing/formulating a PTS (and any other wood-based substrates) to supply a substrate environment (air, water, and stability) for various crops and the array of grower operations is essential. Reproducible and economical construction of PTS is needed so that standardization of substrate processing may be imposed with consistent results. A knowledge of particle size distribution for a wood substrate can be used to characterize its expected physical properties and provide guidelines for how to process wood chips (hammermilling) to achieve the $\mathrm{CC}$ and AS desired for crop production. As a result, uniformity of plant production, be it greenhouse or nursery crops, should be enhanced and more predictable.

Based on the previous studies conducted on other substrates and works conducted on PTSs, a preliminary experiment was conducted to determine if grinding (hammering) a mixture of peatmoss or aged $\mathrm{PB}$ with unground pine chips would result in a more homogenous product (substrate). We found that mixing peatmoss $(25 \%)$ with a coarsely hammered PTS (produced by hammering wood chips with no screen in the hammermill) was just as effective as grinding the peatmoss with the pine wood chips during PTS manufacturing in terms of increasing CC of the substrate and subsequent plant growth of marigold. However, hammering aged PB $(25 \%)$ with pine wood chips was more effective in improving physical properties and plant growth than mixing PB with PTS after hammering. Based on these initial observations, the purpose of this work was to evaluate the influence of: 1) combining PTSs of different particles sizes; and 2) adding peatmoss, aged $\mathrm{PB}$, and sand to PTSs of different particle sizes on substrate physical properties and plant growth.

\section{Materials and Methods}

Combining pine tree substrates of different particle sizes. Fifteen-year-old loblolly pine trees were harvested and delimbed on 10 May 2008 and chipped on 24 June with a Bandit Chipper (Model 200; Bandit Industries, Inc., Remus, MI). Coarse pine wood chips were ground on 24 June in a hammermill (Meadows Mills, Inc., North Wilkesboro, NC) fitted with either a 4.76-mm screen or with no screen (NS) with the latter resulting in a coarser PTS than with the screen. These two substrates were then combined at the following proportions: $100 \% 4.76 \mathrm{~mm}, 75 \% 4.76$ $\mathrm{mm}: 25 \% \mathrm{NS}, 50 \% 4.76 \mathrm{~mm}: 50 \% \mathrm{NS}, 25 \%$ $4.76 \mathrm{~mm}: 75 \% \mathrm{NS}$, and 100\% NS. Control treatments of PL $[80 \%$ peatmoss $/ 20 \%$ perlite (v/v; Premier Tech, Quebec, Canada)] and $100 \%$ aged PB were included. Each substrate was amended with calcium sulfate $\left(\mathrm{CaSO}_{4}\right)$ at $0.6 \mathrm{~kg} \cdot \mathrm{m}^{-3}$. Substrate $\mathrm{pH}$ for all PTS treatments was $\approx 6.0$; therefore, no $\mathrm{pH}$ adjustment (lime addition) was necessary. Peat-lite and PB were amended with dolomitic limestone at 5.25 and $3.5 \mathrm{~kg} \cdot \mathrm{m}^{-3}$, respectively, to raise $\mathrm{pH}$ to 6.0. On 27 June, 12-d-old marigold seedlings grown in 144-unit plug trays using Fafard Superfine Germinating Mix (Conrad 
Table 1. Physical and chemical properties of pine tree substrates (PTS), peat-lite, and pine bark and growth data for marigold grown for four weeks in $2008 .{ }^{z}$

\begin{tabular}{|c|c|c|c|c|c|c|c|c|c|}
\hline Substrate & $\begin{array}{c}\text { Container } \\
\text { capacity }{ }^{\mathrm{y}}(\% \mathrm{vol})\end{array}$ & $\begin{array}{c}\text { Air } \\
\text { space }^{\mathrm{x}}(\% \text { vol })\end{array}$ & $\begin{array}{c}\text { Available } \\
\text { water }^{w}(\% \text { vol })\end{array}$ & $\begin{array}{c}\text { Percent } \\
\text { fines }^{\mathrm{v}}(\% \text { mass })\end{array}$ & $\begin{array}{c}\text { Shoot dry } \\
\text { wt (g) }\end{array}$ & $\begin{array}{c}\text { Growth } \\
\text { index }{ }^{\mathrm{u}}(\mathrm{cm})\end{array}$ & $\begin{array}{c}\text { Root } \\
\text { rating }^{t}\end{array}$ & $\mathrm{pH}^{\mathrm{s}}$ & $\mathrm{EC}^{\mathrm{sr}}\left(\mathrm{dS} \cdot \mathrm{m}^{-1}\right)$ \\
\hline $100 \%$-PTS-4.76 & $52.6 b^{p}$ & $36.3 \mathrm{de}$ & $35.7 \mathrm{a}$ & $14.9 \mathrm{a}$ & $9.8 \mathrm{ab}$ & $34.1 \mathrm{a}$ & $2.0 \mathrm{bc}$ & $5.3 \mathrm{e}$ & $1.5 \mathrm{~b}$ \\
\hline $75 \%$-PTS-4.76 & $47.1 \mathrm{c}$ & $40.7 \mathrm{~cd}$ & $31.9 \mathrm{ab}$ & $9.4 \mathrm{~b}$ & $9.6 \mathrm{bc}$ & $34.2 \mathrm{a}$ & $1.5 \mathrm{~cd}$ & $5.5 \mathrm{~d}$ & $1.3 \mathrm{c}$ \\
\hline $50 \%$-PTS-4.76 & $43.3 \mathrm{c}$ & $43.8 \mathrm{bc}$ & $34.7 \mathrm{a}$ & $7.6 \mathrm{bc}$ & $9.1 \mathrm{~cd}$ & $32.7 \mathrm{ab}$ & $2.2 \mathrm{bc}$ & $5.7 \mathrm{bc}$ & $1.3 \mathrm{c}$ \\
\hline $25 \%$-PTS-4.76 & $40.4 \mathrm{~d}$ & $47.7 \mathrm{ab}$ & $26.8 \mathrm{bc}$ & $5.0 \mathrm{c}$ & $8.8 \mathrm{~d}$ & $32.6 \mathrm{ab}$ & $2.7 \mathrm{ab}$ & $5.7 \mathrm{bc}$ & $1.2 \mathrm{c}$ \\
\hline $100 \%$-PTS-NS & $35.7 \mathrm{e}$ & $49.2 \mathrm{a}$ & $23.8 \mathrm{c}$ & $2.3 \mathrm{~d}$ & $8.1 \mathrm{e}$ & $31.9 \mathrm{bc}$ & $3.0 \mathrm{a}$ & $6.0 \mathrm{a}$ & $1.2 \mathrm{c}$ \\
\hline Peat-lite $^{\circ}$ & $61.7 \mathrm{a}$ & $21.3 \mathrm{f}$ & $37.5 \mathrm{a}$ & $14.7 \mathrm{a}$ & $10.1 \mathrm{ab}$ & $30.9 \mathrm{c}$ & $1.2 \mathrm{~d}$ & $5.6 \mathrm{c}$ & $2.0 \mathrm{a}$ \\
\hline Pine bark & $48.0 \mathrm{c}$ & $33.0 \mathrm{e}$ & $27.8 \mathrm{bc}$ & $7.9 \mathrm{~b}$ & $10.4 \mathrm{a}$ & $33.0 \mathrm{ab}$ & $1.2 \mathrm{~d}$ & $5.8 \mathrm{~b}$ & $1.3 \mathrm{c}$ \\
\hline
\end{tabular}

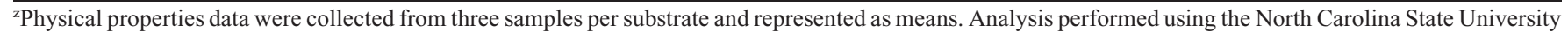
Porometer method (Fonteno et al., 1995).

${ }^{y}$ Container capacity is (wet weight - oven dry weight) $\div$ volume of the sample.

${ }^{\mathrm{x}}$ Air space is the volume of water drained from the sample $\div$ volume of the sample.

${ }^{\mathrm{w}}$ Available water $=$ container capacity - unavailable water.

${ }^{v}$ Percent fines = percent mass of three oven-dried 150-g substrate samples less than $0.5 \mathrm{~mm} .1 \mathrm{~mm}=0.0394 \mathrm{inch}$.

"Growth index [(height + widest width + perpendicular width $) \div 3$ ]

'Root rating of 1 to 3 assigned to the rootballs of plants $=1$ being the least amount of roots and 3 being the most amount of roots.

${ }^{\mathrm{s}} \mathrm{pH}$ and electrical conductivity (EC) of substrate solution obtained by the pour-through method (Wright, 1986).

${ }^{\mathrm{r}} 1 \mathrm{ds} \cdot \mathrm{m}^{-1}=1 \mathrm{mmho} / \mathrm{cm}$.

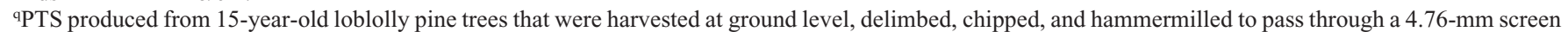
and mixed with PTS produced with no screen (NS) at $25 \%$ increments.

'Means separated within columns using Duncan's multiple range test $(P \leq 0.05)$.

${ }^{\circ}$ Peat-lite composed of $80 \%$ peatmoss $/ 20 \%$ perlite $(\mathrm{v} / \mathrm{v})$.

Fafard, Inc., Agawam MA) were transplanted into $10-\mathrm{cm}$ square (1-L) plastic containers with the different substrates. Plants were glasshouse-grown in Blacksburg, VA, and fertilized at each watering with a $300 \mathrm{mg} \cdot \mathrm{L}^{-1}$ $\mathrm{N}$ solution (beaker-applied) from a Peters 20N-4.4P-16.6K Peat-Lite Special (The Scotts Co., Marysville, OH). Plants were irrigated throughout the study at the same time as determined by the general weight of containers and irrigated to achieve a $20 \%$ leaching fraction, which was determined in preliminary studies to be the most similar for all substrates considering their difference in CC percentages. Substrate solution was extracted using the pour-through (PT) method (Wright, 1986) on 15 July and analyzed for $\mathrm{pH}$ and electrical conductivity (EC) using a Hanna HI 9811 instrument (Hanna Instruments, Woonsocket, RI). Growth index [GI; (height + widest width + perpendicular width)/ 3] was determined on 22 July; shoots were severed at the substrate surface, oven-dried for $5 \mathrm{~d}$ at $65{ }^{\circ} \mathrm{C}$, and dry weights recorded. The root ball of each plant was given a subjective (visual) root rating of 1 to 3 based on the density of roots on the outside/surface of the root ball with 1 being the least amount of roots and 3 being the most. The rating was given to each side of each root ball, of each plant, and averaged $(n=4)$. Physical properties including AS, CC, total porosity, and bulk density (BD) were determined on three replicate samples of each substrate using the North Carolina State University (NCSU) Porometer method as described by Fonteno et al. (1995). Available water was determined on substrates by calculating CC unavailable water. Unavailable water (the amount of water held in the substrate at 1.5 $\mathrm{MPa}$ or greater) was determined with the $100-\mathrm{cm}^{3}$ cores using the pressure plate extraction in a procedure developed by Milks et al. (1989).

The experimental design was completely randomized with seven substrates and eight replications per substrate for a total of 56 containers. Data were analyzed using SAS (Version 9.1; SAS Institute, Inc., Cary, NC) with treatment means separated by Duncan's multiple range test $(\alpha=0.05)$.

Pine tree substrate with various amendments. Fifteen-year-old loblolly pine trees were harvested and delimbed on $27 \mathrm{Feb}$. 2008 and chipped on 25 Mar. with a Bandit Chipper. These coarse pine chips were further ground on $26 \mathrm{Mar}$. in a hammermill fitted with different screen sizes: 4.76, 6.35, 9.54, and $15.8 \mathrm{~mm}$ as well as one PTS hammered without any screen (NS; coarse texture) in place. Each of the five PTSs were then amended (mixed) by volume with $10 \%$ sand (PTS-S), 25\% peatmoss (PTS-PM), or left unamended (PTS) for a total of 15 substrates. Additional substrates were produced by grinding (hammering) coarse pine wood chips with 25\% aged PB (PTS-HPB) with each of the five hammermill screens mentioned. These five PTSs were then amended with $10 \%$ sand (PTS-HPBS) or left unamended for a total of 10 substrates. Control treatments included PL and 100\% aged PB for a total of 27 substrates evaluated in this study. Each substrate was amended with $\mathrm{CaSO}_{4}$ at $0.6 \mathrm{~kg} \cdot \mathrm{m}^{-3}$. Peat-lite and PTSHPB substrates were amended with dolomitic limestone at 5.25 and $3.5 \mathrm{~kg} \cdot \mathrm{m}^{-3}$, respectively. On 15 Apr., marigold seedlings grown in 144-unit plug trays using Fafard Superfine Germinating Mix were transplanted into 10 -cm square (1-L) plastic containers with the 27 different substrates. Plants were glasshouse-grown in Blacksburg, VA, and fertilized at each watering with a $300 \mathrm{mg} \cdot \mathrm{L}^{-1} \mathrm{~N}$ solution (beaker-applied) from a Peters $20 \mathrm{~N}$ 4.4P-16.6K Peat-Lite Special (The Scotts Co.). Plants were irrigated throughout the study at the same time as determined by the general weight of containers and irrigated to achieve a $20 \%$ leaching fraction, which was determined in preliminary studies to be the most similar for all substrates considering their difference in CC percentages. Substrate solution was extracted using the
PT method on 23 Apr., 30 Apr., and 9 May and analyzed for $\mathrm{pH}$ and $\mathrm{EC}$ using a Hanna HI 9811 instrument. On 15 May, GI was determined and shoots were severed at the substrate surface, oven-dried for $5 \mathrm{~d}$ at $65{ }^{\circ} \mathrm{C}$, and dry weights recorded. The root ball of each plant was rated as previously described.

Physical properties of each substrate were determined preplant on three replicate samples of each substrate using the NCSU Porometer method as described previously. Particle size distribution of 150-g oven-dried substrate samples was determined with 14 sieves (ranging from greater than $6.3 \mathrm{~mm}$ to less than $0.063 \mathrm{~mm}$ ) plus a bottom pan. Sieves and pan were shaken for 10 min with a RX-29 Ro-Tap sieve shaker (278 oscillations/min, 150 taps/min; W.S. Tyler, Mentor, $\mathrm{OH})$ and the particle fractions retained on each sieve and the amount that passed through the smallest sieve and retained by the sieve pan were weighed. As a result of small quantities of substrate particles on several of the sieve pans, and to simplify the presentation of data and discussion of results in this article, contents of sieve pans close in size to one another were combined resulting in a total of six sizes: greater than $2.0,1.0,0.5,0.25,0.125$, and 0.063 plus the bottom pan.

The experimental design was completely randomized with 27 substrates and eight replications per substrate for a total of 216 containers. Data were analyzed with the analysis of variance procedure of SAS with treatment means separated by Duncan's multiple range test $(\alpha=0.05)$. Data were also subjected to regression analysis using SigmaPlot (Version 9.01; SPSS, Inc., Chicago, IL).

Azalea and spirea growth in amended pine tree substrate. Fifteen-year-old loblolly pine trees were harvested on 14 Apr. 2008 and chipped on 16 Apr. with a Bandit Chipper. These coarse pine chips were further ground on 16 Apr. in a hammermill fitted with either a $9.35-\mathrm{mm}$ screen or with no 
Table 2. Particle size distribution of peat-lite (PL), pine bark (PB), and pine tree substrate (PTS) with various amendments. ${ }^{z}$

\begin{tabular}{|c|c|c|c|c|c|c|c|c|c|c|}
\hline \multirow[b]{2}{*}{ Screen size ${ }^{w}$} & \multicolumn{7}{|c|}{ Sieve opening $(\mathrm{mm})^{\mathrm{y}}$} & \multicolumn{3}{|c|}{ Texture group ( $\%$ mass $)^{x}$} \\
\hline & Greater than 2.0 & 1.0 & 0.5 & 0.25 & 0.125 & 0.063 & $\overline{\mathrm{Pan}}$ & Coarse & Medium & Fine \\
\hline & \multicolumn{10}{|c|}{$P T S^{v}$} \\
\hline $4.76 \mathrm{~mm}$ & 9.2 & 46.9 & 26.5 & 10.5 & 5.6 & 1.2 & 0.1 & $9.2 \mathrm{e}^{\mathrm{u}}$ & $73.4 \mathrm{a}$ & $17.5 \mathrm{a}$ \\
\hline $6.35 \mathrm{~mm}$ & 20.5 & 51.2 & 17.6 & 6.8 & 3.4 & 0.6 & 0.0 & $20.5 \mathrm{~d}$ & $68.7 \mathrm{~b}$ & $10.8 \mathrm{~b}$ \\
\hline $9.35 \mathrm{~mm}$ & 49.1 & 28.9 & 12.4 & 5.7 & 2.9 & 0.9 & 0.1 & $49.1 \mathrm{c}$ & $41.3 \mathrm{c}$ & $9.6 \mathrm{~b}$ \\
\hline $15.9 \mathrm{~mm}$ & 63.5 & 22.1 & 8.7 & 3.4 & 1.7 & 0.4 & 0.1 & $63.5 \mathrm{~b}$ & $30.8 \mathrm{~d}$ & $5.7 \mathrm{c}$ \\
\hline No screen & .2 & 16.0 & 8.3 & \multicolumn{6}{|c|}{$P T S-S^{t}$} & $6.4 \mathrm{c}$ \\
\hline $4.76 \mathrm{~mm}$ & 4.2 & 30.8 & 20.5 & 29.4 & 13.8 & 1.2 & 0.0 & $4.2 \mathrm{c}$ & $51.4 \mathrm{a}$ & $44.5 \mathrm{a}$ \\
\hline & 20.7 & 23.0 & 16.0 & 21.8 & 16.4 & 1.9 & 0.1 & $20.7 \mathrm{~b}$ & $39.0 \mathrm{~b}$ & $40.3 \mathrm{ab}$ \\
\hline $\mathrm{mm}$ & 26.1 & 25.5 & 12.9 & 20.3 & 13.6 & 1.5 & 0.1 & $26.1 \mathrm{~b}$ & $38.4 \mathrm{~b}$ & $5.5 \mathrm{bc}$ \\
\hline $15.9 \mathrm{~mm}$ & 41.1 & 18.0 & 9.7 & 18.2 & 11.4 & 1.5 & 0.1 & $41.1 \mathrm{a}$ & $27.7 \mathrm{c}$ & $31.1 \mathrm{~cd}$ \\
\hline No screen & \multicolumn{10}{|c|}{$P T S-P M^{S}$} \\
\hline $4.76 \mathrm{~mm}$ & 1.7 & 38.6 & 27.8 & 11.8 & 6.8 & 2.7 & 0.5 & $11.7 \mathrm{c}$ & $66.4 \mathrm{a}$ & $21.8 \mathrm{a}$ \\
\hline & .4 & 43.7 & 17.4 & 8.3 & 4.9 & 2.0 & 0.4 & $3.4 \mathrm{~b}$ & $61.1 \mathrm{~b}$ & $5.5 \mathrm{~b}$ \\
\hline 9.3 & 25.8 & 37.3 & 19.1 & 8.9 & 6.2 & 2.3 & 0.3 & $5.9 \mathrm{~b}$ & $56.4 \mathrm{~b}$ & $17.7 \mathrm{~b}$ \\
\hline $15.9 \mathrm{~mm}$ & 51.1 & 19.9 & 11.7 & 8.7 & 5.8 & 2.3 & 0.6 & $51.1 \mathrm{a}$ & $31.6 \mathrm{c}$ & $17.3 \mathrm{~b}$ \\
\hline \multirow[t]{2}{*}{ No screen } & 55.0 & 16.9 & 11.5 & 8.2 & 6.0 & 2.0 & 0.5 & $55.0 \mathrm{a}$ & $28.4 \mathrm{c}$ & $16.7 \mathrm{~b}$ \\
\hline & \multicolumn{10}{|c|}{$P T S-H P B^{r}$} \\
\hline $4.76 \mathrm{~mm}$ & 2.5 & 29.8 & 34.2 & 19.2 & 11.2 & 2.8 & 0.4 & $2.5 \mathrm{e}$ & $64.0 \mathrm{~b}$ & $33.5 \mathrm{a}$ \\
\hline & 8.1 & 42.1 & 27.0 & 12.0 & 8.0 & 2.4 & 0.4 & $8.1 \mathrm{~d}$ & $69.1 \mathrm{a}$ & $22.8 \mathrm{~b}$ \\
\hline $9.35 \mathrm{~mm}$ & 18.1 & 44.9 & 20.4 & 10.2 & 5.1 & 1.2 & 0.1 & $18.1 \mathrm{c}$ & $65.4 \mathrm{ab}$ & $16.5 \mathrm{c}$ \\
\hline $15.9 \mathrm{~mm}$ & 48.6 & 20.6 & 13.2 & 9.4 & 6.5 & 1.4 & 0.2 & $48.6 \mathrm{~b}$ & $33.8 \mathrm{c}$ & $17.6 \mathrm{c}$ \\
\hline \multirow[t]{2}{*}{ No screen } & 63.4 & 15.6 & 9.7 & 6.0 & 3.9 & 1.1 & 0.3 & $63.4 \mathrm{a}$ & $25.3 \mathrm{~d}$ & $11.4 \mathrm{~d}$ \\
\hline & \multicolumn{10}{|c|}{$P T S-H P B S$} \\
\hline & 1. & 18.6 & 21.7 & 28.9 & 24.6 & 4.2 & 0.5 & $1.6 \mathrm{~d}$ & $40.2 \mathrm{a}$ & $58.1 \mathrm{a}$ \\
\hline 6. & 8 & 25.4 & 19.2 & 27.1 & 18.2 & 1.9 & 0.1 & $8.1 \mathrm{~d}$ & $44.6 \mathrm{a}$ & $47.3 \mathrm{~b}$ \\
\hline $9.35 \mathrm{~mm}$ & 16.7 & 23.8 & 16.8 & 24.3 & 16.4 & 1.8 & 0.1 & $16.7 \mathrm{c}$ & $40.6 \mathrm{a}$ & $42.7 \mathrm{bc}$ \\
\hline $15.9 \mathrm{~mm}$ & 29.1 & 13.1 & 12.2 & 22.2 & 19.5 & 3.5 & 0.3 & $29.1 \mathrm{~b}$ & $25.4 \mathrm{~b}$ & $45.6 \mathrm{~b}$ \\
\hline \multirow[t]{4}{*}{ No screen } & 39.5 & 16.3 & 11.3 & 20.0 & 11.7 & 1.2 & 0.1 & $39.5 \mathrm{a}$ & $27.5 \mathrm{~b}$ & $33.0 \mathrm{c}$ \\
\hline & \multicolumn{7}{|c|}{ Screen size (S) } & $\leq 0.0001$ & $\leq 0.0001$ & $\leq 0.000$ \\
\hline & \multicolumn{7}{|c|}{ Amendment (A) } & $\leq 0.0001$ & $\leq 0.0001$ & $\leq 0.000$ \\
\hline & & & & & & & $\mathrm{S} * \mathrm{~A}$ & $\leq 0.0001$ & $\leq 0.0001$ & $\leq 0.000$ \\
\hline$P L^{p}$ & 31.3 & 15.4 & 16.0 & 14.7 & 13.4 & 6.8 & 2.3 & 31.3 & 31.4 & 37.3 \\
\hline $\mathrm{PB}$ & 52.6 & 21.2 & 14.7 & 7.1 & 3.0 & 1.1 & 0.3 & 52.6 & 35.9 & 11.5 \\
\hline Sand & 0.0 & 0.2 & 6.6 & 39.8 & 43.6 & 8.9 & 0.9 & 0.0 & 6.8 & 93.2 \\
\hline
\end{tabular}

${ }^{\mathrm{z}}$ Values are means of three oven-dried samples.

${ }^{\mathrm{y}} 1 \mathrm{~mm}=0.0394$ inch.

${ }^{\mathrm{x}}$ Texture grouping: coarse $=$ greater than $2.0 \mathrm{~mm}$; medium $=$ greater than 0.5 to less than $2.0 \mathrm{~mm}$; fine $=$ less than $0.5 \mathrm{~mm}$.

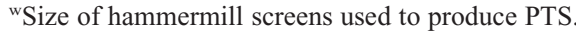

PTS produced from 15-year-old loblolly pine trees that were harvested at ground level, delimbed, chipped, and hammermilled.

"Means separated within column by Duncan's multiple range test $(P \leq 0.05)(\mathrm{n}=3)$. Means followed by the same letter are not significantly different.

TPTS-S produced by amending PTS with $10 \%$ sand (9:1 ratio).

sPTS-PM produced by amending (mixed after grinding) PTS with $25 \%$ peatmoss (3:1 ratio).

rPTS-HPB produced by grinding fresh pine wood chips with $25 \%$ aged PB (3:1 ratio) in a hammermill. qPTS-HPBS produced by amending 10\% sand (9:1 ratio) to PTS-HPB.

PPL composed of $80 \%$ peatmoss $/ 20 \%$ perlite $(\mathrm{v} / \mathrm{v})$.

screen in place (NS). Both substrates were amended (by vol) with $10 \%$ sand (PTS-S) or left unamended (PTS). Additionally, substrates were produced by hammering coarse pine chips together with $25 \%$ aged PB (PTSHPB) using either the $9.35-\mathrm{mm}$ screen or no screen method as mentioned previously. The PTS-HPB was left unamended or amended with $10 \%$ sand (PTS-HPBS). Control treatments included $100 \%$ PB and PB plus $10 \%$ sand (PB-S) for a total of 10 substrates. Each substrate was amended with $\mathrm{CaSO}_{4}$ at 0.6 $\mathrm{kg} \cdot \mathrm{m}^{-3}$, and the PB used was amended with dolomitic limestone at $3.6 \mathrm{~kg} \cdot \mathrm{m}^{-3}$ before grinding with the wood chips. On 17 Apr., liners of spirea (Spiraea nipponica Maxim. 'Snowmound') and azalea (Rhododendron $\times$ hybrida 'Girard Pleasant White') $(10 \mathrm{~cm}$ tall in $64-\mathrm{cm}^{3}$ containers) were potted in $3.8-\mathrm{L}$ plastic containers filled with the 10 different substrates described previously. Osmocote Plus (15N-3.9P-10K; The Scotts Co.) was postplant top-dressed onto all containers at 3.5 and $5.25 \mathrm{~kg} \cdot \mathrm{m}^{-3}$, respectively, for azalea and at 5.25 and $7.0 \mathrm{~kg} \cdot \mathrm{m}^{-3}$, respectively, for spirea. Plants were grown on a gravel ground bed in a greenhouse in Blacksburg, VA, and overhead-irrigated (by hand) as needed to achieve an approximate $25 \%$ leaching fraction. Average day and night greenhouse air temperatures were 26 and $22{ }^{\circ} \mathrm{C}$, respectively. Substrate solution was extracted using the PT method on 23 Apr., 22 May, 28 June, 29 July, and 7 Aug.; solutions were analyzed for $\mathrm{pH}$ and EC using a Hanna HI 9811 instrument. On 7 Aug.. GI was determined, and shoots were severed at the substrate surface, oven-dried, and weighed. A root rating of 1 to 5 was given to each plant based on the density of roots on the outside of the root ball with 1 being the least amount of roots and 5 being the most.

The experimental design was completely randomized with 10 substrates and 10 replications per substrate for a total of 100 containers. Data were analyzed with SAS with substrate treatment means separated by Duncan's multiple range test $(\alpha=0.05)$ and differences in screen size analyzed by the least significant difference procedure.

\section{Results and Discussion}

Combining pine tree substrates of different particle sizes. Container capacity for $100 \%$ PTS-NS was $35.7 \%$ (Table 1). Increasing the proportion of finely ground PTS-4.76 in the more coarsely ground PTSNS increased the CC from $40.4 \%$ for the $25 \%$-PTS- $4.76 \%$ to $52.6 \%$ for $100 \%$-PTS4.76. Container capacity for $100 \%$-PTS-4.76 was lower than for PL but was higher than PB. Although small proportions of PTS-4.76 ( $50 \%$ or less) added to the coarse PTS-NS did not provide enough fine particles (less than $0.5 \mathrm{~mm}$ ) to produce a PTS with the recommended $\mathrm{CC}$ of at least $45 \%$, these data do indicate the potential of altering $\mathrm{CC}$ by combining different wood particle sizes (Table 1). Adding a more finely ground PTS produced with a $1.59-\mathrm{mm}$ screen (containing $45 \%$ fines; data from previously unpublished work by these authors) rather than $100 \%$ PTS-4.76 (14.9\% fines; Table 1), would have increased the fraction of fine particles and the CC, most likely to equal that of PL and PB. In the case of this experiment, the incremental affect of adding PTS-4.76 to PTS-NS (2.3\% fines) increased the percent fines from 5.0\% in $25 \%$-PTS- $4.76 \%$ to $9.4 \%$ in $75 \%$-PTS4.76 , the latter of which was comparable to PB (Table 1). The $14.9 \%$ fines in $100 \%$-PTS4.76 was equal to the percent found in PL. The $\approx 10 \%$ to $15 \%$ fines needed to obtain a desired CC in a $100 \%$ PTS in this study (compared with PL or PB) has also been noted in previous unpublished research by these authors that showed that a $100 \%$ PTS substrate with $15 \%$ fines corresponds to a CC of $\approx 45 \%$ to $50 \%$, the lower end of the acceptable range for a container substrate. Thus, the percent fines of a PTS substrate should be at least $10 \%$ to $15 \%$ to achieve an adequate $\mathrm{CC}$ for the substrate and this benchmark can be attained with either sufficient grinding or by mixing various proportions of different particle size PTSs. Available water of PTS- 4.76 at $100 \%, 75 \%$, and $50 \%$ fractions was equal to the available water in PL, and available water (AW) in all PTSs was equal or higher that the AW percent of $\mathrm{PB}$ (Table 1).

Marigold shoot dry weight followed a similar trend as $\mathrm{CC}$ in response to increasing proportions of PTS-4.76 with maximum dry weight occurring at $100 \%$-PTS-4.76 in which dry weight was equal to that for PL and $\mathrm{PB}$ (Table 1). Adding PTS-4.76 to PTS-NS at rates of $25 \%$ or more increased plant GI 
Table 3. Physical properties of peat-lite (PL), pine bark (PB), and pine tree substrates (PTS) with various amendments. $^{\mathrm{z}}$

\begin{tabular}{|c|c|c|c|c|c|c|c|}
\hline \multirow[b]{2}{*}{ Screen size ${ }^{y}$} & \multicolumn{7}{|c|}{ Substrate and amendment } \\
\hline & PTS $^{x}$ & PTS-S $^{w}$ & PTS-PM $^{v}$ & PTS-HPB $^{\mathrm{u}}$ & PTS-HPBS $^{t}$ & $\mathrm{PL}^{\mathrm{s}}$ & PB \\
\hline & \multicolumn{7}{|c|}{ Container capacity $(\% \mathrm{vol})^{r}$} \\
\hline $4.76 \mathrm{~mm}$ & $50.5 \mathrm{c}^{\mathrm{q}}$ & $49.5 \mathrm{c}$ & $57.2 \mathrm{~b}$ & $60.3 \mathrm{a}$ & $61.5 \mathrm{a}$ & $61.2 \mathrm{a}$ & $50.3 \mathrm{c}$ \\
\hline $6.35 \mathrm{~mm}$ & $44.2 \mathrm{~d}$ & $46.5 \mathrm{~d}$ & $51.7 \mathrm{c}$ & $56.5 \mathrm{~b}$ & $54.9 \mathrm{~b}$ & $61.2 \mathrm{a}$ & $50.3 \mathrm{c}$ \\
\hline $9.35 \mathrm{~mm}$ & $41.2 \mathrm{e}$ & $46.0 \mathrm{~d}$ & $52.6 \mathrm{~b}$ & $47.8 \mathrm{~cd}$ & $52.0 \mathrm{~b}$ & $61.2 \mathrm{a}$ & $50.3 \mathrm{bc}$ \\
\hline $15.9 \mathrm{~mm}$ & $38.1 \mathrm{~d}$ & $41.6 \mathrm{c}$ & $53.1 \mathrm{~b}$ & $50.3 \mathrm{~b}$ & $52.3 \mathrm{~b}$ & $61.2 \mathrm{a}$ & $50.3 \mathrm{bc}$ \\
\hline No screen & $41.0 \mathrm{~d}$ & $44.0 \mathrm{~d}$ & $54.3 \mathrm{~b}$ & $48.6 \mathrm{c}$ & $49.4 \mathrm{c}$ & $61.2 \mathrm{a}$ & $50.3 \mathrm{c}$ \\
\hline \multirow[t]{2}{*}{ Significance $^{\mathrm{p}}$} & NS & NS & NS & NS & $\mathrm{L}^{*}$ & - & - \\
\hline & $\mathrm{Q}^{* * *}$ & $\mathrm{Q}^{* * *}$ & NS & $\mathrm{Q}^{* *}$ & $\mathrm{Q}^{* *}$ & - & - \\
\hline$P$ values ${ }^{\circ}$ & \multicolumn{7}{|c|}{ Screen size $(S)=\leq 0.0001 ;$ Amendment $(A)=\leq 0.0001 ; S^{*} A=\leq 0.0001$} \\
\hline & \multicolumn{7}{|c|}{ Air space $(\% \text { vol })^{n}$} \\
\hline $4.76 \mathrm{~mm}$ & $36.5 \mathrm{a}$ & $33.9 \mathrm{ab}$ & $30.9 \mathrm{~b}$ & $24.9 \mathrm{c}$ & $19.3 \mathrm{~d}$ & $17.6 \mathrm{~d}$ & $24.8 \mathrm{c}$ \\
\hline $6.35 \mathrm{~mm}$ & $42.0 \mathrm{a}$ & $37.0 \mathrm{ab}$ & $35.8 \mathrm{bc}$ & $30.5 \mathrm{~cd}$ & $25.5 \mathrm{~d}$ & $17.6 \mathrm{e}$ & $24.8 \mathrm{~d}$ \\
\hline $9.35 \mathrm{~mm}$ & $43.2 \mathrm{a}$ & $36.5 \mathrm{abc}$ & $34.4 \mathrm{bc}$ & $38.5 \mathrm{ab}$ & $29.5 \mathrm{~cd}$ & $17.6 \mathrm{e}$ & $24.8 \mathrm{ed}$ \\
\hline $15.9 \mathrm{~mm}$ & $48.2 \mathrm{a}$ & $39.0 \mathrm{~b}$ & $34.1 \mathrm{~b}$ & $35.5 \mathrm{~b}$ & $26.5 \mathrm{c}$ & $17.6 \mathrm{~d}$ & $24.8 \mathrm{c}$ \\
\hline No screen & $43.5 \mathrm{a}$ & $34.9 \mathrm{~b}$ & $32.8 \mathrm{~b}$ & $38.0 \mathrm{~b}$ & $32.6 \mathrm{~b}$ & $17.6 \mathrm{~d}$ & $24.8 \mathrm{c}$ \\
\hline \multirow[t]{2}{*}{ Significance } & NS & NS & NS & NS & $\mathrm{L}^{*}$ & - & - \\
\hline & $\mathrm{Q}^{*}$ & $\mathrm{Q}^{*}$ & NS & $\mathrm{Q}^{*}$ & $\mathrm{Q}^{* *}$ & - & - \\
\hline$P$ values & \multicolumn{7}{|c|}{ Screen size $(S)=\leq 0.0001 ;$ Amendment $(A)=\leq 0.0001 ; S^{*} A=0.0007$} \\
\hline & \multicolumn{7}{|c|}{ Total porosity $(\% \text { vol })^{m}$} \\
\hline $4.76 \mathrm{~mm}$ & $86.9 \mathrm{ab}$ & $83.4 \mathrm{abc}$ & $88.1 \mathrm{a}$ & $85.2 \mathrm{abc}$ & $79.8 \mathrm{bcd}$ & $78.8 \mathrm{bc}$ & $75.1 \mathrm{~d}$ \\
\hline $6.35 \mathrm{~mm}$ & $86.2 \mathrm{a}$ & $83.5 \mathrm{ab}$ & $87.5 \mathrm{a}$ & $87.0 \mathrm{a}$ & $80.4 \mathrm{abc}$ & $78.8 \mathrm{bc}$ & $75.1 \mathrm{c}$ \\
\hline $9.35 \mathrm{~mm}$ & $84.3 \mathrm{ab}$ & $82.6 \mathrm{ab}$ & $87.0 \mathrm{a}$ & $86.3 \mathrm{a}$ & $81.5 \mathrm{ab}$ & $78.8 \mathrm{ab}$ & $75.1 \mathrm{~b}$ \\
\hline $15.9 \mathrm{~mm}$ & $86.2 \mathrm{ab}$ & $80.6 \mathrm{abc}$ & $87.3 \mathrm{a}$ & $85.8 \mathrm{ab}$ & $78.8 \mathrm{bc}$ & $78.8 \mathrm{bc}$ & $75.1 \mathrm{c}$ \\
\hline No screen & $84.5 \mathrm{ab}$ & $78.9 \mathrm{bc}$ & $87.1 \mathrm{a}$ & $86.6 \mathrm{a}$ & $82.0 \mathrm{abc}$ & $78.8 \mathrm{bc}$ & $75.1 \mathrm{c}$ \\
\hline \multirow[t]{2}{*}{ Significance } & NS & $\mathrm{L}^{*}$ & NS & NS & NS & - & - \\
\hline & NS & $\mathrm{Q}^{*}$ & NS & NS & NS & - & - \\
\hline$P$ values & \multicolumn{7}{|c|}{ Screen size $(\mathrm{S})=0.6766 ;$ Amendment $(\mathrm{A})=\leq 0.0001 ; \mathrm{S} * \mathrm{~A}=0.8199$} \\
\hline & \multicolumn{7}{|c|}{ Bulk density $\left(g \cdot \mathrm{cm}^{-3}\right)^{l}$} \\
\hline $4.76 \mathrm{~mm}$ & $0.15 \mathrm{c}$ & $0.24 \mathrm{ab}$ & $0.15 \mathrm{c}$ & $0.16 \mathrm{c}$ & $0.29 \mathrm{a}$ & $0.14 \mathrm{c}$ & $0.22 \mathrm{~b}$ \\
\hline $6.35 \mathrm{~mm}$ & $0.16 \mathrm{c}$ & $0.25 \mathrm{ab}$ & $0.15 \mathrm{c}$ & $0.16 \mathrm{c}$ & $0.26 \mathrm{a}$ & $0.14 \mathrm{c}$ & $0.22 \mathrm{~b}$ \\
\hline $9.35 \mathrm{~mm}$ & $0.16 \mathrm{c}$ & $0.26 \mathrm{a}$ & $0.15 \mathrm{c}$ & $0.15 \mathrm{c}$ & $0.27 \mathrm{a}$ & $0.14 \mathrm{c}$ & $0.22 \mathrm{~b}$ \\
\hline $15.9 \mathrm{~mm}$ & $0.17 \mathrm{c}$ & $0.26 \mathrm{a}$ & $0.15 \mathrm{~cd}$ & $0.18 \mathrm{c}$ & $0.26 \mathrm{a}$ & $0.14 \mathrm{~d}$ & $0.22 \mathrm{~b}$ \\
\hline No screen & $0.17 \mathrm{c}$ & $0.27 \mathrm{a}$ & $0.17 \mathrm{c}$ & $0.18 \mathrm{c}$ & $0.29 \mathrm{a}$ & $0.14 \mathrm{~d}$ & $0.22 \mathrm{~b}$ \\
\hline \multirow[t]{2}{*}{ Significance } & $\mathrm{L}^{* *}$ & $\mathrm{~L}^{*}$ & $\mathrm{~L} * * *$ & $\mathrm{~L}^{*}$ & NS & - & - \\
\hline & $\mathrm{Q}^{* * * *}$ & $\mathrm{Q}^{* * *}$ & $\mathrm{Q}^{* * * *}$ & $\mathrm{Q}^{* *}$ & $\mathrm{Q}^{* *}$ & - & - \\
\hline$P$ values & \multicolumn{7}{|c|}{ Screen size $(\mathrm{S}) \leq 0.0001 ;$ Amendment $(\mathrm{A}) \leq 0.0001 ; \mathrm{S} * \mathrm{~A} \leq 0.0001$} \\
\hline
\end{tabular}

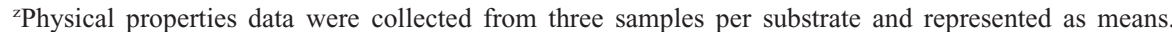
Analysis performed using the North Carolina State University Porometer method (Fonteno et al., 1995). ${ }^{y}$ Size of hammermill screens used to produce PTS.

xPTS produced from 15-year-old loblolly pine trees that were harvested at ground level, delimbed, chipped, and hammer-milled.

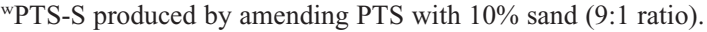

vPTS-PM produced by amending (mixed after grinding) PTS with 25\% peatmoss (3:1 ratio).

uPTS-HPB produced by grinding fresh pine wood chips with $25 \%$ aged PB (3:1 ratio) in a hammermill. tPTS-HPBS produced by amending 10\% sand (9:1 ratio) to PTS-HPB.

sPL composed of $80 \%$ peatmoss $/ 20 \%$ perlite $(\mathrm{v} / \mathrm{v})$.

${ }^{\mathrm{r}}$ Container capacity is (wet weight - oven dry weight) $\div$ volume of the sample.

${ }^{\mathrm{q}}$ Means separated within row by Duncan's multiple range test $(P \leq 0.05)(\mathrm{n}=8)$. Means followed by the same letter are not significantly different.

${ }^{\mathrm{p}} \mathrm{L}=$ linear; $\mathrm{Q}=$ quadratic response for concentration at $*, * *$, or $* * *$

${ }^{\circ}$ NS (nonsignificant) or significant at $* P \leq 0.05, * * 0.01$, or $* * * 0.001$.

${ }^{n}$ Air space is the volume of water drained from the sample $\div$ volume of the sample.

${ }^{\mathrm{m}}$ Total porosity is equal to container capacity + air space.

${ }^{\mathrm{I} B u l k}$ density after forced-air drying at $105^{\circ} \mathrm{C}$ for $48 \mathrm{~h}$.

values; these values were the same or higher than for GI values of PL- and PB-grown plants. Root ratings were higher in PTS treatments compared with PL or PB (except for $75 \%$-PTS-4.76), likely reflective of the generally higher percent AS in PTS than that in PL and PB. Substrate solution $\mathrm{pH}$ increased as the percent of PTS-NS increased (Table 1). Substrate solution EC was higher in PL than the other substrates, a result that has been noted in other studies (Jackson et al., 2008b)

Pine tree substrate with various amendments. The particle size distribution in the formulated substrates was influenced by the interaction of the four amendments $(P$ $\leq 0.0001$ for all particle texture groups; Table 2). Percent fines decreased as the hammermill screen size increased for the five PTSs. Percent fines increased when peatmoss was mixed with PTS (PTS-PM) and when $25 \%$ PB was hammered with PTS (PTSHPB) compared with PTS alone at all screen sizes. Adding sand to the PTSs showed a dramatic increase in fines compared with adding peatmoss or PB alone. This is a result of the high content of fine particles in the sand $(93.2 \%)$, the reason for its inherently high BD compared with PTS, PL, or PB. Container capacity increased as screen size decreased except for PTS-PM in which there was no change (Table 3). Amending PTSs with sand did not generally increase CC. Container capacity generally increased when $100 \%$ PTS was amended with $25 \%$ peat (PTS$\mathrm{PM}$ ) or hammered with $25 \%$ PB (PTS-HPB) compared with that of $100 \% \mathrm{~PB}$. Container capacity for PTS-HPB or PB plus $10 \%$ sand (PTS-HPBS) produced with a 4.76-mm screen was at least $60 \%$ and was the same as the CC of PL. Container capacity for all PTSs amended with peatmoss, sand, or hammered with $\mathrm{PB}$ was within the recommended range of $45 \%$ to $65 \% \mathrm{CC}$ for container substrates (Yeager et al., 2007) with the exception of PTS-NS and 15.9-mm PTS-S, which were slightly below the lower range (Table 3 ); 4.76-mm PTS was within the recommended range without any amendments as a result of its finer particle size. Treatments with acceptable CC (Table 3) also contained $15 \%$ or more fine particles (Table 2).

Air space decreased as screen size decreased [the inverse of the influence of screen size on CC (Table 3)] as a result of increased fines (Table 2), except for PTS-PM, which did not change, which was also the case with CC (Table 3). Similar to these results in PTS, the reduction of container substrate AS by the addition of fines (less than $0.5 \mathrm{~mm}$ ) from PB or peatmoss in a PB (or other coarse) substrate is well documented (Handreck, 1983). Air space also generally decreased with the addition of amendments (PTS versus amended substrates). In most cases, AS was considerably higher in PTS treatments than in PL or PB with the exception of PTS-HPBS for most screen sizes, and the AS was higher than the recommended range of $10 \%$ to $30 \%$ for container substrates. However, a higher than recommended AS may be acceptable if CC is in the proper range, which was the case for PTS-PM or PTS-HPB treatments. Total porosity was generally higher for PTS than for $\mathrm{PB}$ as a result of the higher AS for all screen sizes of PTS (Table 3). Amending PTS with sand (PTS-S) and PTS-HPB with sand (PTSHPBS) resulted in the highest $\mathrm{BD}$ (Table 3 ). The increase in $\mathrm{BD}$ as a result of sand amendment has been documented in a 100\% PB substrate (Brown and Pokorny, 1975; Pokorny and Henny, 1984a). The BD of unamended PTS as well as PTS-PM or PTS-HPB was similar to PL and lower than PB.

Reflective of the substrate $\mathrm{CC}$, marigold shoot dry weight increased as screen size decreased regardless of PTS amendment (Table 4). Amending PTS with peatmoss, PTS-HPB, and PTS-HPBS with $4.76 \mathrm{~mm}$ PTS resulted in shoot dry weight equal or better than those grown in PL and PB. Shoot growth in $6.35 \mathrm{~mm}$ PTS-HPBS was equal to PL and PB; $6.35 \mathrm{~mm}$ PTS-HPB resulted in growth equal to $\mathrm{PB}$ but not PL. Marigold shoot dry weight for all other treatments was less than those for PL and PB. Growth index of plants decreased with increasing screen size in all treatments with the exception of PTS$\mathrm{PM}$, which corresponds to the result that CC was not altered by screen size in the PTS-PM substrates (Table 4). The PTS-PM, PTS-HPB, 
Table 4. Plant growth of marigold grown in peat-lite (PL), pine bark (PB), and pine tree substrates (PTS) with various amendments for 4 weeks in 2008.

\begin{tabular}{|c|c|c|c|c|c|c|c|}
\hline \multirow[b]{2}{*}{ Screen size ${ }^{t}$} & \multicolumn{7}{|c|}{ Substrate and amendment } \\
\hline & PTS $^{z}$ & PTS-S $^{y}$ & PTS-PM $^{x}$ & PTS-HPB $^{w}$ & PTS-HPBS $^{v}$ & $\mathrm{PL}^{\mathrm{u}}$ & $\mathrm{PB}$ \\
\hline & \multicolumn{7}{|c|}{ Shoot dry wt (g) } \\
\hline $4.76 \mathrm{~mm}$ & $6.5 \mathrm{~d}^{\mathrm{s}}$ & $7.1 \mathrm{c}$ & $7.9 \mathrm{~b}$ & $8.2 \mathrm{~b}$ & $8.9 \mathrm{a}$ & $8.3 \mathrm{~b}$ & $8.1 \mathrm{~b}$ \\
\hline $6.35 \mathrm{~mm}$ & $5.8 \mathrm{e}$ & $6.6 \mathrm{~d}$ & $7.4 \mathrm{c}$ & $7.6 \mathrm{bc}$ & $8.0 \mathrm{abc}$ & $8.3 \mathrm{a}$ & $8.1 \mathrm{ab}$ \\
\hline $9.35 \mathrm{~mm}$ & $5.6 \mathrm{e}$ & $6.5 \mathrm{~d}$ & $7.4 \mathrm{bc}$ & $7.0 \mathrm{~cd}$ & $7.6 \mathrm{abc}$ & $8.3 \mathrm{a}$ & $8.1 \mathrm{ab}$ \\
\hline $15.9 \mathrm{~mm}$ & $3.6 \mathrm{~d}$ & $5.1 \mathrm{c}$ & $6.8 \mathrm{~b}$ & $5.6 \mathrm{c}$ & $6.9 \mathrm{~b}$ & $8.3 \mathrm{a}$ & $8.1 \mathrm{a}$ \\
\hline No screen & $3.8 \mathrm{e}$ & $4.9 \mathrm{~d}$ & $6.4 \mathrm{~b}$ & $5.1 \mathrm{~d}$ & $5.7 \mathrm{c}$ & $8.3 \mathrm{a}$ & $8.1 \mathrm{a}$ \\
\hline \multirow[t]{2}{*}{ Significance $^{r}$} & $\mathrm{~L}^{* *}$ & $\mathrm{~L} * * *$ & $\mathrm{~L}^{* *}$ & $\mathrm{~L} * * *$ & $\mathrm{~L} * * *$ & - & - \\
\hline & $\mathrm{Q}^{* * *}$ & $\mathrm{Q}^{* * *}$ & $\mathrm{Q}^{* * *}$ & $\mathrm{Q}^{* * *}$ & $\mathrm{Q}^{* * *}$ & - & - \\
\hline$P$ values ${ }^{\mathrm{q}}$ & \multicolumn{7}{|c|}{ Screen size $(S)=\leq 0.0001 ;$ Amendment $(A)=\leq 0.0001 ; S * A=0.0002$} \\
\hline & \multicolumn{7}{|c|}{ Growth index $(\mathrm{cm})^{p}$} \\
\hline $4.76 \mathrm{~mm}$ & $30.3 \mathrm{c}$ & $31.2 \mathrm{abc}$ & $31.4 \mathrm{abc}$ & $32.7 \mathrm{a}$ & $32.1 \mathrm{ab}$ & $30.7 \mathrm{bc}$ & $31.2 \mathrm{bc}$ \\
\hline $6.35 \mathrm{~mm}$ & $30.2 \mathrm{~b}$ & $30.7 \mathrm{ab}$ & $31.2 \mathrm{ab}$ & $32.1 \mathrm{a}$ & $31.4 \mathrm{ab}$ & $30.7 \mathrm{ab}$ & $31.2 \mathrm{ab}$ \\
\hline $9.35 \mathrm{~mm}$ & $28.7 \mathrm{~d}$ & $29.8 \mathrm{~cd}$ & $31.3 \mathrm{ab}$ & $32.4 \mathrm{a}$ & $31.1 \mathrm{~b}$ & $30.7 \mathrm{bc}$ & $31.2 \mathrm{ab}$ \\
\hline $15.9 \mathrm{~mm}$ & $26.2 \mathrm{c}$ & $28.8 \mathrm{~b}$ & $30.4 \mathrm{a}$ & $30.1 \mathrm{ab}$ & $30.8 \mathrm{a}$ & $30.7 \mathrm{a}$ & $31.2 \mathrm{a}$ \\
\hline No screen & $27.0 \mathrm{~d}$ & $29.1 \mathrm{c}$ & $30.3 \mathrm{ab}$ & $29.6 \mathrm{bc}$ & $30.2 \mathrm{abc}$ & $30.7 \mathrm{ab}$ & $31.2 \mathrm{a}$ \\
\hline \multirow[t]{2}{*}{ Significance } & NS & NS & NS & $\mathrm{L} * * *$ & $\mathrm{~L}^{*}$ & - & - \\
\hline & $\mathrm{Q}^{* * *}$ & $\mathrm{Q}^{* * *}$ & NS & $\mathrm{Q}^{* * *}$ & $\mathrm{Q}^{*}$ & - & - \\
\hline$P$ values & \multicolumn{7}{|c|}{ Screen size $(\mathrm{S})=\leq 0.0001 ; \operatorname{Amendment}(\mathrm{A})=\leq 0.0001 ; \mathrm{S} * \mathrm{~A}=0.0064$} \\
\hline & \multicolumn{7}{|c|}{ Root rating ${ }^{\circ}$} \\
\hline $4.76 \mathrm{~mm}$ & $2.2 \mathrm{~b}$ & $3.0 \mathrm{a}$ & $2.2 \mathrm{~b}$ & $2.0 \mathrm{~b}$ & $2.7 \mathrm{a}$ & $1.0 \mathrm{c}$ & $1.2 \mathrm{c}$ \\
\hline $6.35 \mathrm{~mm}$ & $2.3 \mathrm{~b}$ & $2.8 \mathrm{a}$ & $2.3 \mathrm{~b}$ & $2.0 \mathrm{~b}$ & $2.2 \mathrm{~b}$ & $1.0 \mathrm{c}$ & $1.2 \mathrm{c}$ \\
\hline $9.35 \mathrm{~mm}$ & $2.7 \mathrm{ab}$ & $3.0 \mathrm{a}$ & $2.2 \mathrm{c}$ & $2.3 \mathrm{bc}$ & $2.2 \mathrm{c}$ & $1.0 \mathrm{~d}$ & $1.2 \mathrm{~d}$ \\
\hline $15.9 \mathrm{~mm}$ & $2.7 \mathrm{ab}$ & $3.0 \mathrm{a}$ & $2.2 \mathrm{c}$ & $2.3 \mathrm{bc}$ & $2.2 \mathrm{c}$ & $1.0 \mathrm{~d}$ & $1.2 \mathrm{~d}$ \\
\hline No screen & $1.8 \mathrm{~b}$ & $2.8 \mathrm{a}$ & $2.2 \mathrm{~b}$ & $1.8 \mathrm{~b}$ & $2.3 \mathrm{~b}$ & $1.0 \mathrm{c}$ & $1.2 \mathrm{c}$ \\
\hline Significance & NS & NS & NS & $\mathrm{L}^{*}$ & NS & - & - \\
\hline & NS & NS & NS & NS & NS & - & - \\
\hline$P$ values & \multicolumn{7}{|c|}{ Screen size $(S)=0.0884 ;$ Amendment $(A)=\leq 0.0001 ; S^{*} A=0.0009$} \\
\hline
\end{tabular}

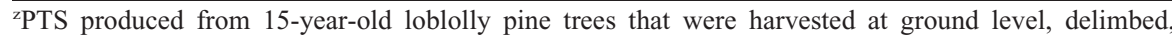
chipped, and hammermilled to pass through each of the listed screen sizes.

yPTS-S produced by amending PTS with 10\% sand (9:1 ratio).

xPTS-PM produced by amending (mixed after grinding) PTS with 25\% peatmoss (3:1 ratio).

wPTS-HPB produced by grinding fresh pine wood chips with $25 \%$ aged PB (3:1 ratio) in a hammermill. vPTS-HPBS produced by amending $10 \%$ sand (9:1 ratio) to PTS-HPB.

uPL composed of $80 \%$ peatmoss $/ 20 \%$ peat-lite $(\mathrm{v} / \mathrm{v})$.

'Size of hammermill screens used to produce PTS.

sMeans separated within row by Duncan's multiple range test $(P \leq 0.05)(\mathrm{n}=8)$. Means followed by the same letter are not significantly different.

${ }^{\mathrm{r}} \mathrm{L}=$ linear; $\mathrm{Q}=$ quadratic response for concentration at $*, * *$, or $* * *$.

${ }^{\mathrm{q}_{\mathrm{NS}}}$ (nonsignificant) or significant at $* P \leq 0.05, * * 0.01$, or $* * * 0.001$.

${ }^{\mathrm{p}}$ Growth index [(height + widest width + perpendicular width $\left.) \div 3\right]$.

${ }^{\circ}$ Root rating of 1 to 3 assigned to the root balls of all plants $=1$ being the least amount of roots and 5 being the most amount of roots.

and PTS-HPBS treatments (at all screen sizes) resulted in plants with GI equal to that of PL or PB. All plants, regardless of the substrate in which they were grown, were of high quality with no nutritional-related disorders (deficiency or toxicity). Fewer differences in GI compared with dry weight between plants grown in PTS and PL or PB has been noted with past experiments (Fain et al., 2008b; Jackson et al., 2008b). Root rating was unaffected by screen size except that PTS-HPB produced with NS was lower than for the other screen sizes (Table 4), but root ratings were higher for all PTSs than for PL and PB, especially for PTS-S. The generally higher root ratings for plants grown in PTS compared with plants grown in PL and PB could be a result of the higher AS in the PTSs (Table 3). However, because there was not a relationship between increasing AS as screen size increased, the increased root ratings for PTS may have been a result of the lower EC (nutrient levels; Table 5) with the PTS treatments compared with PL, because root growth is known to be more prolific under lower nutrition conditions rel- ative to shoot growth as shown by Niemiera and Wright (1982).

As a result of similar $\mathrm{pH}$ and $\mathrm{EC}$ values for the three PT dates (Weeks 2, 3, and 4 after treatment start), data were averaged over time (Table 5). $\mathrm{pH}$ values of the PTS treatments increased with increasing screen size and were higher for the PTSs compared with PL or PB except for 4.76 and $6.35 \mathrm{~mm}$ PTSs either unamended or amended with peatmoss or sand, in which case $\mathrm{pH}$ was equal to that of PL and higher than PB (Table 5). EC in PTSs decreased with increasing screen size and was always lower than the EC of PL. The EC of PTS produced with smaller screens was similar to that of PB and less than PB in PTSs produced with larger screens (Table 5). The latter result is most likely related to the higher nutrient retention capacity of a substrate with a relatively high fines content (Table 2) of a small screen-produced substrate compared with a substrate produced by a large screenproduced substrate.

These results confirm previous results that a $100 \%$ PTS produced with a $2.38-\mathrm{mm}$ screen has an adequate amount of small particles and adequate $\mathrm{CC}$ for plant growth comparable to that in PL or PB (Jackson and Wright, 2009a; Saunders et al., 2006). Also, growth in coarser particle PTS produced with a 4.76 - and 6.35$\mathrm{mm}$ screen (Table 4) can be improved by incorporating sand, peat, or hammering wood chips and $\mathrm{PB}$ together, to equal growth of plants grown in PL or PB. The reason for this improvement in growth with decreasing screen size and with the additions of peatmoss and PB is most likely a result of the increased $\mathrm{CC}$ for these substrates (Table 3 ). However, because most of the amended substrates, even for PTS-NS, were within the acceptable CC range for container substrates, more specific irrigation management (watering each substrate individually based on loss of AW from the substrate) could have ameliorated the growth difference between PTSNS and PL or PB. Why sand additions to PTS and PTS-HPB increased growth is unclear because CCs for those substrates were unaffected by its additions (Table 3 ). Similar to these results, Niemiera et al. (1994) has shown that the CC of two PB:S [9:1 and 5:1 $\mathrm{PB}: \mathrm{S}(\mathrm{v} / \mathrm{v})]$ substrates were the same as for a $100 \%$ PB substrate although AS decreased as a result of the sand. Although amending substrates with sand does not increase CC, one possible explanation for the plant growth differences, as shown by Niemiera et al. (1994) in studies with PB, is that the sand significantly increased plant AW in the substrates. Another possible explanation is that the sand increased the water column and the accessibility of water by plant roots in the container by increasing capillary rise (increasing hydraulic conductivity) as a result of increased micropores in the upper region of the container. At the completion of the experiment, when plants were removed from the containers, PTS-S and PTS-HPBS treatments were observed to have sand particles well distributed down the entire (top to bottom) profile of the root ball, evidence that the sand did not settle or filter to the bottom of the pot during irrigations throughout the experimental period. Roots were observed growing in the top $5 \mathrm{~cm}$ of the PTS-S root ball in contrast to PTS and PTS-HPB substrates (that did not have sand), where no roots were visible in the top $5 \mathrm{~cm}$. This observation explains the higher root ratings reported for PTS with sand additions previously discussed (Table 4). This observation led the authors to hypothesize that the sand simply retained water higher in the container, thus facilitating more root growth and water availability, potentially having the greatest positive implication during the first days after plugs were transplanted into the containers when water (and thereby fertilizer) would be held closer to the top of the containers and available for initial plant/plug growth. These observations and hypothesis are supported by Caron et al. (2005) whose research indicated increased subirrigation efficiency (as a result of increased capillary rise) in substrates when increased amounts of fines were added to a substrate composed primarily of bark. A third possibility may be that the sand incorporated 
Table 5. $\mathrm{pH}$ and electrical conductivity (EC) of marigold grown in peat-lite (PL), pine bark (PB), and pine tree substrates (PTS) with various amendments.

\begin{tabular}{|c|c|c|c|c|c|c|c|}
\hline \multirow[b]{2}{*}{ Screen size ${ }^{t}$} & \multicolumn{7}{|c|}{ Substrate and amendment } \\
\hline & PTS $^{z}$ & $\mathrm{PTS}^{\mathrm{P}} \mathrm{S}^{\mathrm{y}}$ & PTS-PM $^{x}$ & PTS-HPB $^{w}$ & PTS-HPBS $^{v}$ & $\mathrm{PL}^{\mathrm{u}}$ & $\mathrm{PB}$ \\
\hline & \multicolumn{7}{|c|}{$p H$} \\
\hline $4.76 \mathrm{~mm}$ & $5.6 \mathrm{c}^{\mathrm{s}}$ & $5.6 \mathrm{c}$ & $5.9 \mathrm{bc}$ & $6.2 \mathrm{a}$ & $6.0 \mathrm{ab}$ & $5.7 \mathrm{c}$ & $5.3 \mathrm{~d}$ \\
\hline $6.35 \mathrm{~mm}$ & $5.8 \mathrm{ab}$ & $5.8 \mathrm{ab}$ & $5.7 \mathrm{ab}$ & $6.0 \mathrm{a}$ & $6.0 \mathrm{a}$ & $5.7 \mathrm{~b}$ & $5.3 \mathrm{c}$ \\
\hline $9.35 \mathrm{~mm}$ & $6.1 \mathrm{a}$ & $5.9 \mathrm{bc}$ & $5.8 \mathrm{~b}$ & $6.1 \mathrm{ab}$ & $6.1 \mathrm{ab}$ & $5.7 \mathrm{~cd}$ & $5.3 \mathrm{~d}$ \\
\hline $15.9 \mathrm{~mm}$ & $6.4 \mathrm{a}$ & $6.3 \mathrm{a}$ & $6.0 \mathrm{~b}$ & $6.2 \mathrm{a}$ & $6.2 \mathrm{a}$ & $5.7 \mathrm{c}$ & $5.3 \mathrm{~d}$ \\
\hline No screen & $6.5 \mathrm{a}$ & $6.4 \mathrm{ab}$ & $6.2 \mathrm{~b}$ & $6.5 \mathrm{a}$ & $6.4 \mathrm{a}$ & $5.7 \mathrm{c}$ & $5.3 \mathrm{~d}$ \\
\hline \multirow[t]{2}{*}{ Significance ${ }^{r}$} & $\mathrm{~L}^{* *}$ & $\mathrm{~L}^{* *}$ & $\mathrm{~L}^{* * *}$ & $\mathrm{~L}^{* * *}$ & $\mathrm{~L}^{* * *}$ & - & - \\
\hline & $\mathrm{Q}^{* * *}$ & $\mathrm{Q}^{* * *}$ & $\mathrm{Q}^{* * *}$ & $\mathrm{Q}^{* * *}$ & $\mathrm{Q}^{* * *}$ & - & - \\
\hline$P$ values $^{\mathrm{q}}$ & \multicolumn{7}{|c|}{ Screen size $(S)=\leq 0.0001 ;$ Amendment $(A)=\leq 0.0001 ; S^{*} A=0.0043$} \\
\hline & \multicolumn{7}{|c|}{$E C\left(d S \cdot m^{-1}\right)^{p}$} \\
\hline $4.76 \mathrm{~mm}$ & $1.80 \mathrm{~b}$ & $1.82 \mathrm{~b}$ & $1.85 \mathrm{~b}$ & $1.62 \mathrm{~b}$ & $1.62 \mathrm{~b}$ & $2.43 \mathrm{a}$ & $1.79 \mathrm{~b}$ \\
\hline $6.35 \mathrm{~mm}$ & $1.62 \mathrm{~b}$ & $1.73 \mathrm{~b}$ & $1.78 \mathrm{~b}$ & $1.75 \mathrm{~b}$ & $1.74 \mathrm{~b}$ & $2.43 \mathrm{a}$ & $1.79 \mathrm{~b}$ \\
\hline $9.35 \mathrm{~mm}$ & $1.50 \mathrm{c}$ & $1.56 \mathrm{bc}$ & $1.83 \mathrm{~b}$ & $1.67 \mathrm{bc}$ & $1.82 \mathrm{~b}$ & $2.43 \mathrm{a}$ & $1.79 \mathrm{bc}$ \\
\hline $15.9 \mathrm{~mm}$ & $1.39 \mathrm{c}$ & $1.40 \mathrm{c}$ & $1.53 \mathrm{bc}$ & $1.35 \mathrm{c}$ & $1.37 \mathrm{c}$ & $2.43 \mathrm{a}$ & $1.79 \mathrm{~b}$ \\
\hline No screen & $1.30 \mathrm{c}$ & $1.29 \mathrm{c}$ & $1.49 \mathrm{c}$ & $1.26 \mathrm{c}$ & $1.28 \mathrm{c}$ & $2.43 \mathrm{a}$ & $1.79 \mathrm{~b}$ \\
\hline \multirow[t]{2}{*}{ Significance } & $\mathrm{L} * * *$ & $\mathrm{~L} * * *$ & $\mathrm{~L}^{* *}$ & $\mathrm{~L} * * *$ & $\mathrm{~L} * * *$ & - & - \\
\hline & $\mathrm{Q}^{* * *}$ & $\mathrm{Q}^{* * *}$ & $\mathrm{Q}^{* * *}$ & $\mathrm{Q} * * *$ & $\mathrm{Q}^{* * *}$ & - & - \\
\hline$P$ values & \multicolumn{7}{|c|}{ Screen size $(S)=\leq 0.0001 ;$ Amendment $(A)=0.0006 ; S * A=0.1024$} \\
\hline
\end{tabular}

${ }^{2}$ PTS produced from 15-year-old loblolly pine trees that were harvested at ground level, delimbed, chipped, and hammermilled.

yPTS-S produced by amending PTS with 10\% sand (9:1 ratio).

${ }^{x}$ PTS-PM produced by amending (mixed after grinding) PTS with $25 \%$ peatmoss (3:1 ratio).

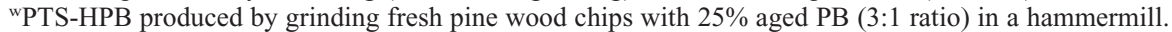
${ }^{\vee}$ PTS-HPBS produced by amending $10 \%$ sand (9:1 ratio) to PTS-HPB.

uPL composed of $80 \%$ peatmoss $/ 20 \%$ peat-lite (v/v).

tSize of hammermill screens used to produce PTS.

sMeans separated within row by Duncan's multiple range test $(P \leq 0.05)(\mathrm{n}=8)$. Means followed by the same letter are not significantly different.

${ }^{\mathrm{r}} \mathrm{L}=$ linear; $\mathrm{Q}=$ quadratic response for concentration at $*, * *$, or $* * *$.

${ }^{\mathrm{q}} \mathrm{NS}$ (nonsignificant) or significant at $* P \leq 0.05, * * 0.01$, or $* * * 0.001$, respectively.

$\mathrm{p} 1 \mathrm{dS} \cdot \mathrm{m}^{-1}=1 \mathrm{mmho} / \mathrm{cm}$.

Table 6. Dry shoot weight $(\mathrm{g})$ and growth index $(\mathrm{GI} ; \mathrm{cm})^{\mathrm{z}}$ of Rhododendron $\times$ hybrida 'Girard's Pleasant White' and Spiraea nipponica 'Snowmound' grown in pine bark (PB) and pine tree substrates (PTS) with various amendments.

\begin{tabular}{|c|c|c|c|c|c|c|}
\hline \multirow[b]{2}{*}{ Screen size ${ }^{t}$} & \multicolumn{6}{|c|}{ Substrate and amendment } \\
\hline & $\mathrm{PTS}^{\mathrm{y}}$ & PTS-S $^{x}$ & PTS-HPB $^{w}$ & PTS-HPBS $^{v}$ & $\mathrm{~PB}$ & $\mathrm{~PB}-\mathrm{S}^{\mathrm{u}}$ \\
\hline & \multicolumn{6}{|c|}{ Azalea dry shoot $w t$} \\
\hline $9.35 \mathrm{~mm}$ & $32.0 \mathrm{ab}^{\mathrm{s}}$ & $35.0 \mathrm{ab}$ & $37.0 \mathrm{a}$ & $34.0 \mathrm{ab}$ & $31.0 \mathrm{~b}$ & $33.0 \mathrm{ab}$ \\
\hline No screen & $25.0 \mathrm{c}$ & $31.0 \mathrm{ab}$ & $26.0 \mathrm{bc}$ & $32.0 \mathrm{a}$ & $31.0 \mathrm{ab}$ & $33.0 \mathrm{a}$ \\
\hline \multirow[t]{2}{*}{$\operatorname{LSD}^{\mathrm{r}}$} & * & NS & * & NS & - & - \\
\hline & \multicolumn{6}{|c|}{ Azalea growth index } \\
\hline $9.35 \mathrm{~mm}$ & $28.0 \mathrm{a}$ & $28.0 \mathrm{a}$ & $29.0 \mathrm{a}$ & $27.0 \mathrm{a}$ & $30.0 \mathrm{a}$ & $29.0 \mathrm{a}$ \\
\hline No screen & $25.0 \mathrm{c}$ & $26.0 \mathrm{bc}$ & $25.0 \mathrm{bc}$ & $28.0 \mathrm{ab}$ & $30.0 \mathrm{a}$ & $29.0 \mathrm{a}$ \\
\hline \multirow[t]{2}{*}{ LSD } & $*$ & NS & $*$ & NS & - & - \\
\hline & \multicolumn{6}{|c|}{ Spirea dry shoot weight } \\
\hline $9.35 \mathrm{~mm}$ & $51.0 \mathrm{~b}$ & $50.0 \mathrm{~b}$ & $58.0 \mathrm{a}$ & $60.0 \mathrm{a}$ & $55.0 \mathrm{ab}$ & $59.0 \mathrm{a}$ \\
\hline No screen & $39.0 \mathrm{~d}$ & $45.0 \mathrm{c}$ & $51.0 \mathrm{~b}$ & $56.0 \mathrm{ab}$ & $55.0 \mathrm{ab}$ & $59.0 \mathrm{a}$ \\
\hline \multirow[t]{2}{*}{ LSD } & * & NS & $*$ & NS & - & - \\
\hline & \multicolumn{6}{|c|}{ Spirea growth index } \\
\hline $9.35 \mathrm{~mm}$ & $53.0 \mathrm{~b}$ & $53.0 \mathrm{~b}$ & $58.0 \mathrm{ab}$ & $61.0 \mathrm{a}$ & $59.0 \mathrm{a}$ & $59.0 \mathrm{a}$ \\
\hline No screen & $52.0 \mathrm{c}$ & $53.0 \mathrm{bc}$ & $55.0 \mathrm{ab}$ & $59.0 \mathrm{a}$ & $59.0 \mathrm{a}$ & $59.0 \mathrm{a}$ \\
\hline \multirow[t]{2}{*}{ LSD } & NS & NS & NS & NS & - & - \\
\hline & \multicolumn{6}{|c|}{ Spirea root rating } \\
\hline $9.35 \mathrm{~mm}$ & $4.0 \mathrm{a}$ & $5.0 \mathrm{a}$ & $3.0 \mathrm{~b}$ & $3.0 \mathrm{~b}$ & $2.0 \mathrm{c}$ & $2.0 \mathrm{c}$ \\
\hline No screen & $4.0 \mathrm{ab}$ & $4.0 \mathrm{a}$ & $3.0 \mathrm{ab}$ & $3.0 \mathrm{~b}$ & $2.0 \mathrm{c}$ & $2.0 \mathrm{c}$ \\
\hline LSD & NS & NS & NS & NS & - & - \\
\hline
\end{tabular}

${ }^{\mathrm{z}}$ Growth index [(height + widest width + perpendicular width $) \div 3$ ]

yPTS produced from 15-year-old loblolly pine trees that were harvested at ground level, delimbed, chipped, and hammermilled.

xPTS-S produced by amending PTS with $10 \%$ sand (9:1 ratio).

wPTS-HPB produced by grinding fresh pine wood chips with $25 \%$ aged PB (3:1 ratio) in a hammermill. vPTS-HPBS produced by amending 10\% sand (9:1 ratio) to PTS-HPB.

uPB-S produced by amending PB with $10 \%$ sand (9:1 ratio).

tSize of hammermill screens used to produce PTS.

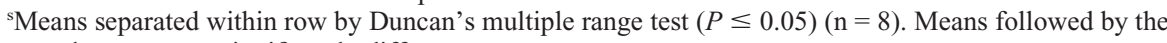
same letter are not significantly different.

${ }^{\mathrm{r}}$ Means separated within columns (between 9.35-mm and no screen) by least significant difference (LSD) at $P \leq 0.05$.

NS $=$ nonsignificant. in these treatments (PTS-S and PTS-HPBS) is providing additional silicon $(\mathrm{Si})$ to the substrate solution, which can improve plant growth. Research on the role of Si in improving plant growth has gained much interest in recent years (Chen et al., 2000; Kamenidou et al., 2008) and some initial unpublished results by one of these authors (Brian Jackson) has shown that sand does significantly increase soluble substrate solution Si concentrations for container-grown plants compared with Si levels in substrates not amended with sand.

Azalea and spirea growth in amended pine tree substrate. There were minor substrate differences for azalea shoot weight for the 9.35-mm PTS treatment; dry weight for PTS-HPB was higher than $100 \%$ PB (Table 6 ). The reason that plant growth for this treatment was higher than azalea plants grown in PB is not understood because plant growth in $\mathrm{PB}$ is normally equal to or higher than plant growth in PTS. Adding sand to the PTS-NS increased azalea shoot dry weight over PTS-NS alone, and adding sand to PTSHPB resulted in growth equal to PB and PB-S (Table 6). Azalea growth indices were the same for all 9.35-mm PTS treatments but shoot dry weight in PTS-NS hammered with PB plus sand was larger than PTS-NS alone and equal to shoot dry weight of plants grown in PB and PL. Shoot dry weight and GI were higher for $9.35-\mathrm{mm}$ PTS than PTSNS, but adding sand resulted in no growth differences between these substrates. Adding sand to PB did not increase azalea shoot growth (Table 6).

For spirea, treatment responses were similar to those of azaleas. For 9.35-mm PTS and PTS-NS, hammering the PTS with PB increased growth over unamended PTS resulting in dry weight equal to PB (Table 6). Adding sand to PTS-HPB (PTS-HPBS) resulted in dry weight equal to both $\mathrm{PB}$ and PB-S. Growth index of both $9.35-\mathrm{mm}$ PTS and PTS-NS were increased by hammering with $\mathrm{PB}$ (PTS-HPB) and hammering with $\mathrm{PB}$ plus sand (PTS-HPBS; Table 6). Adding sand did not increase GI when comparing PTS with PTS-S, PTS-HPB with PTS-HPBS, and PB with PB-S. The $\mathrm{pH}$ of PTS-HPB and PTSHPBS were higher than PB or PL for azalea and spirea (Table 7). All pHs observed in this study were within a suitable range for the production of most nursery crops. However, because PTS is weakly buffered compared with peatmoss or $\mathrm{PB}$, withholding limestone additions to PTS and using acidifying fertilizers could reduce $\mathrm{pH}$ to an acceptable level (Jackson et al., 2009b).

\section{Conclusion}

The studies mentioned show that amending coarsely ground PTS with finer particle PTS or with other materials (peatmoss and aged $\mathrm{PB}$ ) can result in a substrate with comparable physical properties (CC and $\mathrm{AS}$ ) and plant growth as with $100 \% \mathrm{~PB}$ and PL substrates (Table 3). Other similar materials (composts, coconut coir, pine bark fines, 
Table 7. Average electrical conductivity (EC) and $\mathrm{pH}$ levels of substrate solution during the growth of Rhododendron Xhybrida 'Girard's Pleasant White' and Spiraea nipponica 'Snowmound' grown in pine bark (PB) and pine tree substrates (PTS) with various amendments.

\begin{tabular}{|c|c|c|c|c|c|c|}
\hline \multirow[b]{2}{*}{ Screen size ${ }^{u}$} & \multicolumn{6}{|c|}{ Substrate and amendment } \\
\hline & PTS $^{z}$ & PTS-S ${ }^{y}$ & PTS-HPB & PTS-HPBS $^{w}$ & PB & PB-Sv \\
\hline & \multicolumn{6}{|c|}{ Azalea $\mathrm{pH}$} \\
\hline $9.35 \mathrm{~mm}$ & $5.8 \mathrm{~b}^{\mathrm{t}}$ & $6.0 \mathrm{~b}$ & $6.3 \mathrm{a}$ & $6.4 \mathrm{a}$ & $5.9 \mathrm{~b}$ & $5.9 \mathrm{~b}$ \\
\hline No screen & $6.1 \mathrm{abc}$ & $6.0 \mathrm{abc}$ & $6.3 \mathrm{a}$ & $6.3 \mathrm{ab}$ & $5.9 \mathrm{c}$ & $5.9 \mathrm{bc}$ \\
\hline \multirow[t]{2}{*}{$\mathrm{LSD}^{\mathrm{s}}$} & NS & NS & NS & NS & - & - \\
\hline & \multicolumn{6}{|c|}{ Azalea EC $\left(d S \cdot m^{-1}\right)^{q}$} \\
\hline $9.35 \mathrm{~mm}$ & $0.8 \mathrm{a}$ & $0.9 \mathrm{a}$ & $0.8 \mathrm{a}$ & $0.9 \mathrm{a}$ & $0.9 \mathrm{a}$ & $0.8 \mathrm{a}$ \\
\hline No screen & $1.0 \mathrm{a}$ & $0.9 \mathrm{a}$ & $0.8 \mathrm{a}$ & $0.9 \mathrm{a}$ & $0.9 \mathrm{a}$ & $0.8 \mathrm{a}$ \\
\hline \multirow[t]{2}{*}{ LSD } & NS & NS & NS & NS & - & - \\
\hline & \multicolumn{6}{|c|}{ Spirea $p H$} \\
\hline $9.35 \mathrm{~mm}$ & $5.8 \mathrm{bc}$ & $5.7 \mathrm{bc}$ & $6.0 \mathrm{ab}$ & $6.2 \mathrm{a}$ & $5.4 \mathrm{~d}$ & $5.5 \mathrm{~cd}$ \\
\hline No screen & $5.8 \mathrm{~b}$ & $5.8 \mathrm{~b}$ & $6.2 \mathrm{a}$ & $6.2 \mathrm{a}$ & $5.4 \mathrm{c}$ & $5.5 \mathrm{~cd}$ \\
\hline \multirow[t]{2}{*}{ LSD } & NS & NS & NS & NS & - & - \\
\hline & \multicolumn{6}{|c|}{ Spirea EC $\left(d S \cdot m^{-1}\right)$} \\
\hline $9.35 \mathrm{~mm}$ & $0.9 \mathrm{a}$ & $1.2 \mathrm{a}$ & $1.3 \mathrm{a}$ & $1.2 \mathrm{a}$ & $1.2 \mathrm{a}$ & $1.2 \mathrm{a}$ \\
\hline No screen & $1.0 \mathrm{a}$ & $1.0 \mathrm{a}$ & $0.9 \mathrm{a}$ & $1.0 \mathrm{a}$ & $1.2 \mathrm{a}$ & $1.2 \mathrm{a}$ \\
\hline$\underline{L S D}$ & NS & NS & NS & NS & - & - \\
\hline
\end{tabular}

${ }^{2}$ PTS produced from 15-year-old loblolly pine trees that were harvested at ground level, delimbed, chipped, and hammermilled.

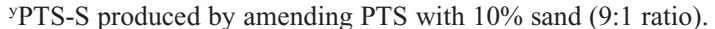

xPTS-HPB produced by grinding fresh pine wood chips with $25 \%$ aged $\mathrm{PB}(3: 1 \mathrm{ratio})$ in a hammermill.

${ }^{\text {wPTS}}$-HPBS produced by amending $10 \%$ sand (9:1 ratio) to PTS-HPB.

vPB-S produced by amending PB with $10 \%$ sand (9:1 ratio).

uSize of hammermill screens used to produce PTS.

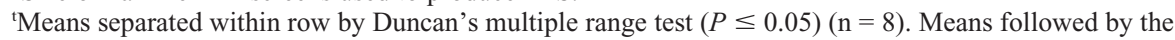
same letter are not significantly different.

${ }^{\mathrm{s}}$ Means separated within columns (between $9.35-\mathrm{mm}$ and no screen) by least significant difference (LSD) at $P \leq 0.05$.

NS $=$ nonsignificant.

and so on) would also likely provide the fines needed in PTS for increased water retention. These other amendments/materials (either organic or inorganic) could potentially be waste/byproduct materials that currently have limited or no use or market for sale, thereby creating an avenue of use/disposal. Depending on the amendment used in PTS construction to supply the fines required, these materials could also possibly improve the CEC of PTS and improve the pH-buffering capacity of PTS, which has been shown to be very low compared with PL (Jackson et al., 2009b). An additional benefit of amendments (fines) to PTS could be improvement of the hydrophysical properties such as hydraulic conductivity, which has been shown to be much higher in PTS than PL (Jackson and Wright, 2009a). The improvement of PTS hydrophysical properties (rewettability, infiltration, hydraulic conductivity, and so on) can be substantially important in more accurately managing irrigation during cultivation.

This research indicates that there needs to be sufficient fine particles in any amendment to achieve at least $10 \%$ to $15 \%$ fines in the resulting substrate for an acceptable CC. Although unaffecting $\mathrm{CC}$, the addition of sand to PTS did improve plant growth, therefore justifying its use as a PTS amendment. The use of sand as an amendment to PTS would likely be used in the construction of PTSs used in nursery crop production because sand can interfere with greenhouse potting machinery. For the construction of PTSs as greenhouse substrates, organic ma- terials (composts, peatmoss, and so on) would be more likely added to supply the fines needed to improve physical properties. Construction of wood substrates from other tree species such as red cedar (Juniperus virginiana $\mathrm{L}$.), which has been most recently reported by Griffin (2009), could also use and benefit from the methods discussed in this article for substrate construction. Previous research reported in 2006 (Rau et al., 2006) has shown that hardwood tree species were unsuitable for use as a container substrate as a result of how quickly they decompose and shrink during crop production (a result of the lower lignin content in hardwoods compared with pines) and as a result of higher amounts of phytotoxins in different wood species. The substrates used in those studies were processed through a 4.76-mm hammermill screen, which, as shown in results in this article, produces a high percentage of small wood particles. These smaller particles would have had accelerated decomposition in containers (compared with larger wood particles), which could have been one explanation for the negative effect on plant growth that was observed. Based on methods of substrate construction (grinding wood to have large particles and amending with other materials for the fine particles) discussed in this work, it is conceivable that hardwood species could be viable for use as a substrate component because the wood particles would be larger, decreasing their decomposition rate.

In addition to the advantages discussed, there may be other advantages to amending coarsely ground PTS with finer ground components. A more coarsely ground PTS would be less expensive to manufacture. Preliminary unpublished studies have shown that the output of PTS-NS from the 25-hp hammermill used in these studies would be $\approx 76$ $\mathrm{kg} / \mathrm{hp} / \mathrm{h}$ compared with only $16 \mathrm{~kg} / \mathrm{hp} / \mathrm{h}$ for a hammermill fitted with a 4.76-mm screen. The output would change with the type and power of hammermill used for wood processing. The lower output for producing a smaller particle PTS (e.g., PTS4.76) would increase inputs such as labor, energy cost for grinding, and require a more expensive hammermill designed to move material (coarse pine chips) through a smaller screen. Whether these savings would offset the cost of adding $25 \%$ peatmoss or aged $\mathrm{PB}$ to PTS would need to be carefully evaluated. One factor that has been observed to affect PTS production rates is the moisture content (\%) of the wood at the time of processing/ grinding. The moisture content of freshly harvested pine trees is normally between $50 \%$ to $55 \%$ based on unpublished observations of these authors (Brian Jackson and Robert Wright), and the amount of moisture in wood chips directly influences the processing rate (reduction of particle size in a hammermill) with higher moisture increasing processing/grinding time and decreasing PTS output from the hammermill. As a result of the longer grinding time of moist wood chips (greater than $50 \%$ moisture), the amount of fines has also been observed by these authors to increase compared with the amount of fines produced from drier wood chips (less than 30\% moisture). Different moisture contents of pine wood chips at the time of grinding is likely the reason why PTS-4.76 was shown to have different percentages of fine particles; $14.9 \%$ fines (Table 1), $17.5 \%$ fines (Table 2), and even $19.5 \%$ fines have been reported by Jackson et al. (2009a). A second factor to be considered when processing wood for use as a container substrate is the type of equipment used for processing (grinding) wood chips. Hammermills appear to be the best choice for this task, but mills can vary considerably between brands (horsepower, air handling devices, motor rpm, hammer tip speed), which will affect the amount of wood that can be processed. These and possibly other factors that could influence PTS construction/processing should be considered and more thoroughly investigated. Regardless of the effect that pregrinding wood moisture will play on the processing of wood, or the equipment used for processing wood into a substrate, the results presented in this article illustrate the feasibility and success in constructing a wood substrate with adequate physical properties and plant growth compared with traditional substrates.

Another important advantage of manufacturing a more coarsely ground PTS may be that the extra fertilizer required for PTS compared with $\mathrm{PB}$ or peatmoss (Jackson et al., 2008a; Wright et al., 2008a) will be 
reduced because other work by these authors has shown that additions of peatmoss and PB to PTS reduce substrate microbial activity and $\mathrm{N}$ immobilization (Jackson and Wright, 2009c). The work by Jackson and Wright (2009c) also showed that microbial activity and $\mathrm{N}$ immobilization in PTS is reduced when PTS particle size increases. As a result of recent industry trends for the production of large woody plants in large containers (greater than $45 \mathrm{~L}$ for over 2 years), production of PTS composed of larger particles (PTS-NS) would decay less rapidly and facilitate substrate stability over these long production periods. The exact extent to which all these factors influence cost of production is not totally understood but with further investigations will become more apparent.

\section{Literature Cited}

Bilderback, T.E. and W.C. Fonteno. 1993. Improving nutrient and moisture retention in pine bark substrates with rockwool and compost combinations. Acta Hort. 342:265-272.

Bilderback, T.E. and R.K. Jones. 2001. Horticultural practices for reducing disease development, p. 387-400. In: Jones, R.K. and D.M. Benson (eds.). Diseases of woody ornamental trees in nurseries. APS Press, St. Paul, $\mathrm{MN}$.

Boodley, J.W. and R. Sheldrake, Jr. 1964. Cornell peat-lite mixes for commercial plant growing. Cornell Ext. Bul. 1104:1-11.

Boyer, C.R., G.B. Fain, C.H. Gilliam, T.V. Gallagher, H.A. Torbert, and J.L. Sibley. 2006. Clean chip residual: A new substrate component for container-grown plants. Proc. Southern Nursery Assn. Res. Conf. 51:22-25.

Boyer, C.R., G.B. Fain, C.H. Gilliam, T.V. Gallagher, H.A. Torbert, and J.L. Sibley. 2008. Clean chip residual: A substrate component for growing annuals. HortTechnology 18:423-432.

Boyer, C.R., C.H. Gilliam, G.B. Fain, T.V. Gallagher, H.A. Torbert, and J.L. Sibley. 2009. Production of woody nursery crops in clean chip residual substrate. J. Environ. Hort. 27:56-62.

Brown, E.F. and F.A. Pokorny. 1975. Physical and chemical properties of media composed of milled pine bark and sand. J. Amer. Soc. Hort. Sci. 100:119-121.

Caron, J., D.E. Elrick, R. Beeson, and J. Boudreau. 2005. Defining critical capillary rise properties for growing media in nurseries. Soil Sci. Soc. Amer. J. 69:794-806.

Chen, J., R.D. Caldwell, C.A. Robinson, and R. Steinkamp. 2000. Silicon: The estranged medium element. Bulletin 341, a series of the Environmental Horticulture Department, Florida Cooperative Extension Service, Institute of Food and Agricultural Sciences, University of Florida.

Fain, G.B., C.H. Gilliam, and J.L. Sibley. 2006. Processed whole pine trees as a substrate for container-grown plants. Proc. Southern Nursery Assn. Res. Conf. 51:59-61.

Fain, G.B., C.H. Gilliam, J.L. Sibley, and C.R Boyer. 2008a. Wholetree substrates derived from three species of pine in production of annual vinca. HortTechnology 18:13-17.

Fain, G.B., C.H. Gilliam, J.L. Sibley, C.R. Boyer, and A.L. Walker. 2008b. Wholetree substrate and fertilizer rate in production of greenhousegrown petunia (Petunia $\times$ hybrida Vilm.) and marigold (Tagetes patula L.). HortScience 43:700-705.
Fonteno, W.C., C.T. Hardin, and J.P. Brewster. 1995. Procedures for determining physical properties of horticultural substrates using the NCSU Porometer. Horticultural Substrates Laboratory, North Carolina State University, Raleigh, NC.

Goodwin, D. 1980. Bark: A valuable resource for horticulture? N.Z. J. Agr. Aug.: 17-19.

Griffin, J. 2009. Eastern red cedar (Juniperus virginiana) as a substrate component for container production of woody plants. HortScience 44:1131.

Gruda, N. and W.H. Schnitzler. 2004. Suitability of wood fiber substrate for production of vegetable transplants. I. Physical properties of wood fiber substrates. Scientia Hort. 100:309-322.

Gruda, N., C. Sippel, and W.H. Schnitzler. 2000. Investigation of physical properties of wood fiber substrates under press pot conditions. Acta Hort. 554:51-55.

Guttormsen, G. 1974. Effects of root medium and watering on transpiration, growth and development of greenhouse crops. I. Effects of compression at varying water levels on physical state of root media and on transpiration and growth of tomatoes. Plant Soil 40:65-81.

Handreck, K. and N. Black. 2005. Growing media for ornamental plants. 3rd Ed. UNSW Ltd., Sydney, Australia.

Handreck, K.A. 1983. Particle size and the physical properties of growing media for containers Commun. Soil Sci. Plant Anal. 14:209-222.

Jackson, B.E. 2008. Chemical, physical, and biological factors influencing nutrient availability and plant growth in a pine tree substrate. $\mathrm{PhD}$ Diss. Virginia Polytechnic Institute \& State Univ., Blacksburg, VA.

Jackson, B.E. and R.D. Wright. 2009a. Pine tree substrate: An alternative and renewable growing media for horticulture crop production. Acta Hort. 819:265-272.

Jackson, B.E. and R.D. Wright. 2009b. Changes in physical properties of a pine tree substrate in containers over time. Comb. Proc. Intl. Plant Prop. Soc. 58:93-98.

Jackson, B.E. and R.D. Wright. 2009c. Wood particle size and peat amendment in pine tree substrates influences microbial activity and nitrogen immobilization. Acta Hort. (Submitted).

Jackson, B.E., R.D. Wright, J.F. Browder, J.R. Harris, and A.X. Niemiera. 2008a. Effect of fertilizer rate on growth of azalea and holly in $\mathrm{PB}$ and pine tree substrates. HortScience 43:1561-1568.

Jackson, B.E., R.D. Wright, and M.C. Barnes. 2008b. Pine tree substrate, nitrogen rate, particle size, and peat amendment affects poinsettia growth and substrate physical properties. HortScience 43:2155-2161.

Jackson, B.E., R.D. Wright, and J.R. Seiler. 2009a. Changes in chemical and physical properties of pine tree substrate and pine bark during longterm nursery crop production. HortScience 44:791-799.

Jackson, B.E., R.D. Wright, and N. Gruda. 2009b. Container medium $\mathrm{pH}$ in a pine tree substrate amended with peatmoss and dolomitic limestone affects plant growth. HortScience 44:1983-1987.

Kamenidou, S., T.J. Cavins, and S. Marek. 2008. Silicon supplements affect horticultural traits of greenhouse-produced ornamental sunflowers. HortScience 43:236-239.

Krafka, B. and F.A. Pokorny. 1979. Bioengineering a pine bark and sand potting medium. Proc. Southern Nursery Assoc. Research Conf. 24:5-9. Laiche, A.J., Jr. and V.E. Nash. 1986. Evaluation of pine bark, pine bark with wood, and pine tree chips as components of a container plant growing media. J. Environ. Hort. 4:22-25.

Lemaire, F., A. Dartigues, and L.M. Riviere. 1980. Properties of substrates with ground pine bark. Acta Hort. 99:67-75.

Matkin, O.A. and P.A. Chandler. 1957. The U.C. type soil mixes, p. 68-85. In: Baker, K.F. (ed.). The U.C. system for producing healthy container grown plants. Calif. Expt. Sta. Ext. Serv. Man. 23.

Milks, R.R., W.C. Fonteno, and R.A. Larson. 1989. Hydrology of horticultural substrates: II. Predicting physical properties of media in containers. J. Amer. Soc. Hort. Sci. 114:53-56.

Nelson, P.V. 2003. Greenhouse operation and management. 6th Ed. Prentice Hall, Englewood Cliffs, NJ.

Niemiera, A.X., T.E. Bilderback, and C.E. Leda. 1994. Pine bark physical characteristics influence pour-through nitrogen concentrations. HortScience 29:789-791.

Niemiera, A.X. and R.D. Wright. 1982. Influence of medium-nitrogen level on growth periodicity of Ilex crenata Thunb. 'Helleri'. Scientia Hort. 17:81-87.

Nkongolo, N.V., J. Caron, F. Gauthier, and M. Tamada. 2000. Organic wastes for improving soil physical properties and enhancing plant growth in container substrates. J. Crop Prod. 3:97-112.

Owen, J.S., Jr., S.L. Warren, T.E. Bilderback, and J.P. Albano. 2007. Industrial mineral aggregate amendment affects physical and chemical properties of pine bark substrates. HortScience 42:1287-1294.

Pokorny, F.A. and B.K. Henny. 1984a. Construction of a milled pine bark and sand medium from component particles. I. Bulk density: A tool for predicting component volumes. J. Amer. Soc. Hort. Sci. 109:770-773.

Pokorny, F.A. and B.K. Henny. 1984b. Construction of a milled pine bark and sand medium from component particles. II. Medium synthesis. J. Amer. Soc. Hort. Sci. 109:774-776.

Prestemon, P. and R.C. Abt. 2002. Timber products supply and demand, p. 229-326. In: Wear, D.N. and J.G. Greis (eds.). The southern forest assessment final technical report. USDA For. Serv. Gen. Tech. Rep. SRS-53.

Rau, B., B.E. Jackson, J.F. Browder, and R.D. Wright. 2006. Wood substrates derived from a variety of tree species affect plant growth. Proc. Southern Nursery Assoc. Research Conf. 51:43-45.

Raviv, M. and J.H. Lieth. 2008. Soilless culture: Theory and practice. Elsevier's Publishing, San Diego, CA.

Samuelson, L.J., J. Butnor, C. Maier, T.A. Stokes, K. Johnsen, and M. Kane. 2008. Growth and physiology of loblolly pine in response to longterm resource management: Defining growth potential in the southern United States. Can. J. For. Res. 38:721-732.

Saunders, T.N., B.E. Jackson, R.D. Wright, and J.F. Browder. 2006. Particle size of a pine chips substrate affects plant growth. Proc. Southern Nursery Assn. Res. Conf. 51:45-47.

Thomas, S. and F.B. Perry, Jr. 1980. Ammonium nitrogen accumulation and leaching from an all pine bark medium. HortScience 15:824-825.

Tyler, H.H., S.L. Warren, T.E. Bilderback, and W.C. Fonteno. 1993. Composted turkey litter: I. effect on chemical and physical properties of a pine bark substrate. J. Environ. Hort. 11:131136.

Wright, R.D. 1986. The pour-through nutrient extraction procedure. HortScience 21:227229. 
Wright, R.D. and J.F. Browder. 2005. Chipped pine logs: A potential substrate for greenhouse and nursery crops. HortScience 40:1513-1515.

Wright, R.D., J.F. Browder, and B.E. Jackson. 2006. Ground pine chips as a substrate for container-grown wood nursery crops. J. Environ. Hort. 24:181-184.

Wright, R.D., B.E. Jackson, J.F. Browder, and J.G. Latimer. 2008a. Growth of chrysanthemum in a pine tree substrate requires additional fertilizer. HortTechnology 18:111-115.

Wright, R.D., B.E. Jackson, and M.C. Barnes. 2008b. Pine tree substrate construction for optimal water holding capacity and air space. Proc. Southern Nursery Assoc. Research Conf. 53:52-54.

Wright, R.D., B.E. Jackson, and M.C. Barnes. 2009. White pine as a pine tree substrate. Proc.
Southern Nursery Assoc. Research Conf. 54:221-223.

Yeager, T.H., D.C. Fare, J. Lea-Cox, J. Ruter, T.E. Bilderback, C.H. Gilliam, A.X. Niemiera, S.L. Warren, T.E. Whitwell, R.D. Wright, and K.M. Tilt. 2007. Best management practices: Guide for producing container-grown plants. 2nd Ed. Southern Nurserymen's Assoc., Marietta, GA. 